\title{
The World of al-Qandūsī (d. 1278/1861)
}

\author{
Prophetology and Calligraphy in Morocco During the First Half of the \\ Nineteenth Century
}

\author{
Francesco Chiabotti and Hiba Abid
}

Each degree of existence is the mirror of the degrees beneath it ... [this refraction continues] until it reaches the Master of Existence (sayyid al-wujūd), Peace and Blessings upon him! For he is the Universal Mirror. All those who are your superiors are, for you, so many mirrors; their gaze sees into you according to how wellpolished the mirror is. And this is what the [Prophet] is alluding to when he says "The believer is the mirror of the believer".

QANDŪsī, Ta'siss

Many articles have been written that seek to assess what might be defined as the "piety of the calligrapher" in Islam. It has already been demonstrated that behind the institution of other branches of Islamic knowledge it is possible to find traces of devotional and ethical practices based on attachment to the Prophet; this is also true in the case of calligraphy. Two important articles discuss the spiritual conception of calligraphy in the Muslim east. First, Annemarie Schimmel, in her study on the "primordial point", quotes an eighteenth century Naqshbandī calligrapher, Mustaqīmzāde, who explains the spiritual compass of individual letters through the secrets contained in the numerical values of the Arabic alphabet: "And how could one deny the mystical meaning of letters and calligraphy [...] since the numerical value of the word khatta $a$ t equals that of the full profession of faith, namely, 619, and the second half of the shahäda, Muhammad Rasūl Allāh, is equal to al-kātib, the scribe, 454 ?"1 According to this sacred numerology, the scribe is identified with the profession of faith. Does Muhammad therefore represent both a source of inspiration and a goal to be

1 Schimmel, "The primordial dot", $35^{2}$.

(C) FRANCESCO CHIABOTTI AND HIBA ABID, 2022 | DOI:10.1163/9789004466739_023

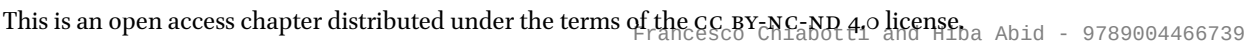


attained through the practice of the art of writing? A few centuries earlier, the Persian poet Jāmī (d. 898/1492) expressed the symbolism of letters by establishing a parallel between the name of the Prophet, 'Ahmad', and the first letter of the alphabet, alif: ${ }^{2}$

The beginning of the foreword of this alphabet

Is the first letter which is in Ahmad.

When the dot of unity showed its stature

And became an alif for Ahmmad's sake,

the diameter of its upright alif

cut the invisible circle of (Divine) Ipseity into halves:

One half is the primordial world,

The other half the contingent word which looks towards non-existence.

In a poem by Bābā Shāh Iṣfahānī (d. 1587-88), the Ādāb al-mashq, Carl W. Ernst also found a symbolic conception of the calligraphic art, one whose rules are here interpreted as so many images of the initiatic journey. Ernst writes that the "Ādāb al-mashq belongs to a special class of writings by calligraphers about calligraphy, but it stands out by its relatively greater emphasis on the internal aspects of the art".3 The Prophet is remarkably present throughout this poem. The calligrapher offers him a special blessing and recognises his central place in the "Book of Existence": the Prophet is the source of the cosmological principles of the "Well-Guarded Tablet" and the "Reed Pen". Bābā Shāh Ișfahāni emphasises the purity that the calligrapher must attain (for purity of art derives from the purity of the artist's heart) and reveals the secrets of the calligraphic art. He also proposes an initiatic method that leads the disciple to realise the mashq khaya $\bar{l} \bar{l}$, a completely interiorised calligraphic practice: here the disciple no longer follows an established external model for his calligraphy, but only an inspiration that comes exclusively from within. From this will spring a beauty that is no longer imitative but the product of an inner contemplation. Ernst concludes his study by postulating that the diffusion of Sufism must have had a profound influence on Persian calligraphers and their circles. The conclusions reached by Christiane Gruber on the basis of research conducted for her monograph on the history of visual representations of the Prophet in Islamic art confirm this. ${ }^{4}$

2 Schimmel, "The primordial dot", 356.

3 Ernst, "The Spirit of Islamic Calligraphy".

4 Gruber, The Praiseworthy One, especially pp. 155-164, for the Naqshbandī order and its specific book culture. 
Nonetheless, one question remains: would it be possible to find parallels from the western part of the Muslim world for these quotations from eastern and Persian sources? Does Maghribi Sufism encounter the calligraphic art? More precisely, did this encounter take the form of a calligraphic expression in which the Prophet played a central role? We can now respond to these questions in the affirmative. In 2009 Morocco's Ministry of Habous and Islamic Affairs published a volume containing the opening pages and paintings from the Dhakhirat al-muhtāj, a summary in several dozen volumes of prayers on the Prophet, richly illustrated with figures symbolically representing the metaphysical and cosmic aspect of the haqiqa muhammadiya, Muhammadan Reality. ${ }^{5}$ In his note at the beginning of the edition, the Minister for Religious Affairs, Ahmed Toufiq, emphasises that the publication of this work, along with the facsimile reproduction elsewhere of other illuminated manuscripts from the culture of devotion to the Prophet in Maghribi Islam (al-Jazūlìs Daläil al-khayrāt and al-Qāḍ̂̄ 'Iyāụ's Shifä̀) aims to "bring out a particular aspect of Moroccan culture: a deeply rooted and defining piety that comes from the profound attachment that Moroccans feel for the blessed person of the Prophet". ${ }^{6}$ This attachment, supported by the milieu of the zawayan, also contributed to the development of the art of the book in Morocco. Specifically, the Daläil and the Dhakhira demonstrate a particular aesthetic, thanks to which certain aspects of the Prophet's physical being can be expressed in a symbolic or allusive manner without ever literally being represented. These works were fundamental in the history of prophetology in the Maghrib and beyond, but we must also speak of the work of a less well-known calligrapher: Abū al-Qāsim al-Qandūsī (d. 1278/1861 in Fez). Each of the authors of the present chapter came to his work independently: Francesco Chiabotti discovered the Sharāb Ahl al-șafā (published by Hammādī in 2008 and then cited by Ruggero Vimercati Sanseverino in his history of Sufism in Fez) while he was trying to establish a corpus of Islamic sources on the Names of the Prophet Muhammad (asma $\left.\bar{a}^{3} a l-n a b \bar{\imath}\right)$. The originality and audacity of the master's doctrine demanded further study. Hiba Abid was studying the calligraphy of Qandūsì's Dalä'il al-khayrāt as part of her doctoral thesis, and was struck by the calligrapher's strong personality. ${ }^{7}$ Hammādī then made important advances in the study of the Kenadsa region and society, and the Zāwiya Ziyāniyya from which Qandūsī came. The next step in the rediscovery of the Kenadsa master was the research on manuscripts undertaken by Abdulaziz Suraqah, along

5 Sharqāwī, Dhakhīrat al-muhtāj.

6 Sharqāwī, Dhakhïrat al-muhtāj, 9.

7 Abid, Les Dalāil al-Khayrāt. 

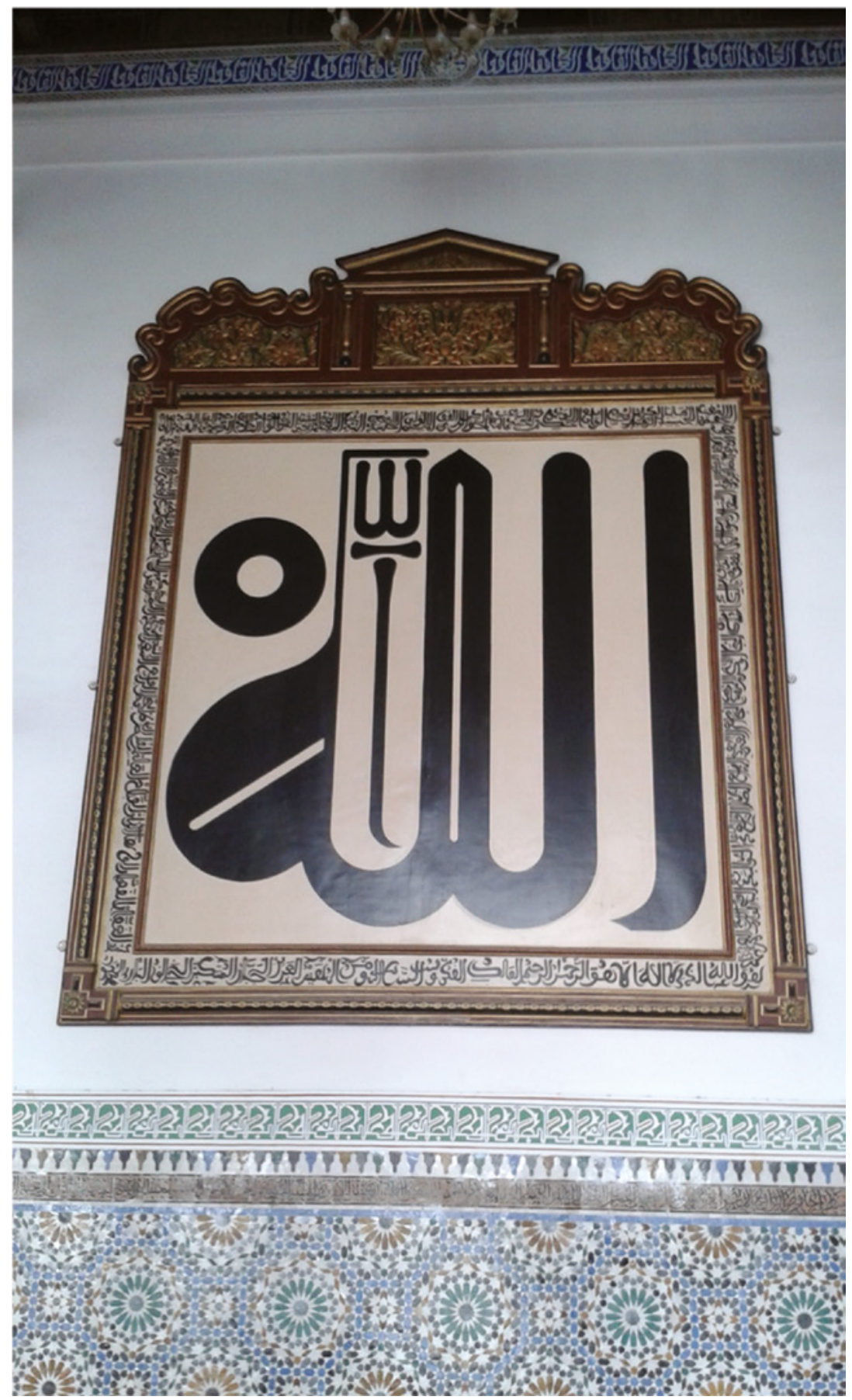

FIGURE 20.1 Fez, Qandūsì's painting at the tomb of Moulay Idris, photo by Francesco Chiabotti 
with his translations, including an English version of the Sharāb and the publication online of several passages from Qandūsī, with the aim of reviving interest in the master's work. ${ }^{8}$ The present contribution springs from an extensive preliminary examination of manuscripts attributed to Qandūsī, undertaken during several trips to Rabat financed by the ANR/DFG PROPHET project. ${ }^{9}$ The questions that project is examining helped guide the approach adopted in our work: we seek to understand how a nineteenth century spiritual man could envisage his art as the emanation of a specific kind of prophetology, and of an intimate relationship with the person of the Prophet. We use two methods: Francesco Chiabotti examines Qandūsīs life and his relationship with the Prophet, and presents the texts in which calligraphy becomes an initiatic art, one through which man can achieve full realisation under the Prophet's own guidance. In the second part of the chapter these doctrinal elements are put side by side with the author's manuscript and calligraphic production. Here Hiba Abid undertakes a paleographic study on al-khatț al-qandūsī, in order better to define the extent of rupture and continuity between Qandūsìs work and the Maghribi calligraphic school.

\section{Seeing the Prophet. Biographical Elements ${ }^{10}$}

Qandūsì's first biographers highlight the discreet nature of this character's life, drawing a portrait of a master whose spiritual work remained largely unknown outside a small group of disciples, until the time, towards the end of his life, when his states of extreme ecstasy revealed the nature of his sanctity and his teaching. His doctrine, especially his prophetology, springs from visionary and ecstatic experience. His first biographer, Muhammad al-Fāțimī al-Sqallī,

8 We are indebted to Abdulaziz Suraqah, who shared with us some manuscripts he had collected.

9 The Royal Library (al-Khizāna al-hasaniyya), in the person of its director Ahmed Binbin, and of Khalid Zahri, who at the time was curator of the library, assisted us greatly, and facilitated our access to the manuscripts preserved in their collections. The National Library of the Kingdom of Morocco has also been of great help, and recently digitised and catalogued its manuscripts by Qandūsī, most of which come from the Kattānī collection (shelved under K). Here we would like to offer special thanks to Nozha Bensaadoun, head of manuscripts. The care and solicitude offered us by the personnel of the department were remarkable; Aziz Laghzaoui helped us verify the codices attributed to Qandūsī.

10 Some exploratory work and reconstitution of Qandūsī's life was realised by 'Abd Allāh Hammādī al-Idrīsī (Al-Faỵ̣ al-quddūs) in 2018. We have based our work on sources he discovered, enriched by the publication of autograph biographical documents and completed by notes drawn from Qandūsì's $T a$ ’sīs. 
presents Qandūsī as one of the Solitary Ones of his time (min al-afrād), who was touched by the mystical divine and then put the experience into writing. The biographer leaves the nature of these writings fairly vague, speaking only of a notebook containing Qandūsì's inspirations. ${ }^{11}$ The exploration of the manuscripts attributed to the master allows us to understand the nature of his writing better: at times it does approach ecstasy, thus confirming al-Sqalli’s impression. The second aspect of Qandūsìs life that is mentioned in his biography is his activity as a calligrapher. His calligraphy became part of spiritual life in Fez: "he was in the habit of writing down, in a majestic and pleasant style, Qurānic verses, acts of faith or similar things; these would be hung in saints' tombs. He was the one who created the Name of Majesty that is hanging in the tomb of Moulay Idrīs." Muḥammad b. Ja'far al-Kattānī specifies that this large drawing of God's name, Allāh, is in the place where the Risāla (al-Qayrāwānī's?) is read, between the prayers for sunset and night. ${ }^{12}$ Most of this information is also presented by Jacfar b. Idrīs al-Kattāni, who was Qandūsìs disciple, in his biographical collection on the saints of Fez, Sharāb al-Muhtadir. He does add a few precious details on Qandūsì's life; for example, his origins in the region of Kenadsa (al-Qanādisa), a palm grove oasis about a day's journey from Figuig. He says that the hidden aspects of the master's personality remained unknown to most people,$^{13}$ despite the fact that Sufi masters had recognised his spiritual rank and been taught by him. He mentions the title of Qandūsì's treatise, al-Ta'siss, extracts of which were published by Muhammad b. Jacfār al-Kattāni in his Salwat al-anfās. The Salwa gives an explanation for the typology of Qandūsì's sanctity: "his state was that of the people of Blame (malämatī). He displayed acts and words that were externally incongruous, but internally just, by which he hid himself from the rest of mankind."14 The sources agree on his profession: he sold herbs in the herb market. Decades after Qandūsì's death, Ja'far b. Muhammad al-Kattānī still knew the works of his that were conserved in part in the Kattānìs private library and was thus able to consult texts that Qandūsì had copied. He mentions the well-known copy of the Qurān in twelve volumes, the final volume of which he was able to consult; he also cites a certain number of copies of al-Jazūlī's Dalā'il al-Khayrāt, two of which are still extant. Qandūsī died at the end of 1861 (Jumādā al-ūlā $1278 \mathrm{H}$ ). The exact location of his grave is unknown. Kattānī's sources say he is

\footnotetext{
11 Wa-qad waqaftu 'alā juz' min wāridātihi, Ḥammādī, Faỵ̣, 7 .

12 Kattānī, Salwat al-anfās, 3:55.

13 idhā jalasa bayna al-nās yakhfā 'anhum amru-hu.

14 Kattānī, op. cit.
} 
buried in the Bāb F'tūh cemetery, in the plot of the Sarrāj family. ${ }^{15}$ Qandūsì's presence in Kattānī's memoirs is mostly due to his ties with Muhammad b. al-Kabīr al-Kattānī (d. 1277/1872), who was initiated into the țaríqa qādiriyya by Qandūsī. His influence is mostly apparent in the doctrine of Muhammadan Reality, and subsequent studies could well go into more detail on the reach of his transmission. The Kattāniyya library possessed numerous manuscripts by Qandūsī, now held in the National Library in Rabat.

The information in these biographical notices is important because it indicates the aspects of the master's personality that made the biggest impression on his contemporaries. But none of them address the central element of Qandūsì's life: his perpetual relationship with the Prophet. In order to grasp the modalities of this relationship, we must examine the writings of the master himself, for disseminated throughout the margins of Qandūsìs manuscript we can find personal notes bearing witness to his visionary universe that is defined by the omnipresence of the Prophetic reality. We will now return to the story of his life and allow him to speak for himself.

In a note conserved in the autograph pages of manuscript $399 \mathrm{~K}$ in the National Library in Rabat, he indicates his ancestry as follows: "Muhammad b. al-Qāsim b. Aḥmad al-Qandūsī, son of the pious saint known by the name of Sayyidī Ahmad, who is buried in Béchar, near Kenadsa. I am a descendant of the Aws and the Anșār [...]."16 Qandūsìs ways of writing his father's name demonstrate the difficulty we face in trying to recover details of his life: Hammādi finds three variants (Qāsim, al-Qāsim, Abū l-Qāsim), all of which appear in the autograph manuscripts. ${ }^{17}$ As one works on Qandūsī's œuvre, one begins to understand that such uncertainty is an important aspect of his way of writing. As we shall see, he admits that he does not pay attention to the formal side of writing. The copyist of the manuscript of the Sharāb ahl al-șafā claims to have corrected the language in the text to make it conform to the rules of Arabic grammar. ${ }^{18}$ But uncertainty is not just a linguistic problem: it also opens the door to a world in which the Prophet himself is communicating and establishing identity. In the colophon of the large Qurān in twelve volumes, he signs himself Muhammad b. Abī l-Qāsim al-Qandūsī mansha'an: he comes from Kenadsa, where he grew up before migrating to Fez. In Kenadsa, he was initiated into the Shädhiliyya-Nāșiriyya-Ziyāniyya Sufi Path by the master

15 Raw dat aw lād Sarrāj. Al-Fāțimī adds "near the mausoleums" (bi-l-qibāb). According to the author of the Salwa, his tomb is covered with zellige tiles.

16 Ms 399 K, National Library of Rabat, fol. 7 .

17 Ḥammādī, Fayḍ, 21.

18 Qandūsī, Sharāb, 55 . 
Muhammad, called ( $\left.a l-\operatorname{mad}^{\prime} \bar{u}\right)$ Ibn 'Abd Allāh, from the lineage of nāșirì ziyān̄i masters. ${ }^{19}$ But to this he adds that he is descended from the Medinese tribe of the Aws, something that has been communicated to him in an unveiling (kashf) by the Prophet himself. ${ }^{20}$ In other texts he specifies that this unveiling took place in a dream vision $\left.\left(r u^{\prime} y \bar{a}\right)\right)^{21}$ " [...] Know that thou art descended from the Anșār, and among the Anșār, [from] the Aws [...]" In this dream the Prophet explains how the Medinese reached the land of Béchar, and then Kenadsa. He tells Qandūsî: "the Anșār are my support and my well-beloved ones; thou art one of them by the surfeit of love thou bearest me and by the abundance of the prayers thou addressest to me. Only the Devil could contest thine ancestry; have a care never to doubt it!"22 An account of a second vision follows, in which Qandūsì's spirit accomplishes a mystical ascension to the seventh heaven - normally associated with Abraham - where he encounters the Prophet sitting on a carpet. The Prophet then takes the shape of a white pearl (durra bay $\bar{a}^{\prime}$ ), while Qandūsī perceives himself as resplendent lights. ${ }^{23}$

In other passages, Qandūsī emphasises the opposition he has had to face from the people of Fez, who were clearly not ready to take his word for all this, even though, for our author, the communication came directly from the Prophet. He insists on the question of ancestry in his principal work, the Ta'siss, in which he adds a few words received from the Prophet:

Among the graces that the Very Generous One (al-Karim, God) has granted me: confirmation directly from the Prophet of my descent (nasab). We are close to him as much through our descent as through our merit (nasab wa-hasab); we know this thanks to the words he (peace and blessings upon him) addressed to us: "Thou art truly my son (anta waladi haqqan), if thou desirest speak; or if thou preferest, be quiet." I then [wanted] to complain to my Master about certain people who contested my descent, but before I could even bring it up he replied: "Those people are demons

19 See Ḥammādī's research on the Ziyāniyya zāwiya in Kenadsa, Hammādī, Hâậirat al-qanādisa.

20 Al-awsī nasaban kashfan mimmā talaqqā 'an sayyid [sic] șālla Allāh 'alayhi wa-sallam. Muș'ḥaf al-Qandūsī, Ms Khizāna al-ḥasaniyya 12613-12, fol. 138a-b. The text was published by Hammādī, Fayḍ, 92. The same affirmation occurs in a line in which Qandūsī signs a brief note about a prayer received in Bāb Ftūh (see below), MS BNRM 1688 D, Taqāyìd, 10: "Muḥammad b. al-Qāsim al-Qandūsī al-Anșārī al-Awsī wa-lā fakhr fì tahquīq al-nasab al-anșārì 'an sayyid șalla Allāh 'alayhi wa-sallam".

21 MS $399 \mathrm{~K}$, fol. 7: [...] min al-ru'yā al-sharīfa fì tahqüq al-nasab al-anșārī [...].

$22 \quad$ Ms $399 \mathrm{~K}$, fol. 7 a.

23 MS $399 \mathrm{~K}$, fol. 7b: fa-'arijat rūḥ̂ ilā l-samā' al-sābi'a fa-wajadtu-hu șalla Allāh 'alayhi wasallam fì bișāț wa-huwa al-durra al-bayḍā' bi-jam' ahl al-haḍra wa-anā anwār (sic) sāțía. 
among the djinns and humankind, do not feel oppressed because of their hearts." And with his noble tongue he told me, "I love thee, and I love those who love thee." On another occasion he again spoke to me, saying, "I am your guarantor, fear nothing." I am only recounting this with the aim of spreading knowledge of God's good actions (al-tahadduth 'an ni'mat Allāh), [and] as a sign of gratitude to Him [... $]^{24}$

We can find echoes of this confirmation from the Prophet in other, similar, accounts of the visions or dreams of masters, in which they found themselves in the personal presence of the Prophet, and had experiences that formed the basis of, or transformed, their identities. For example, the case of Emir Abdelkader (d. 1883) is well known. In the mawqif 13 , he says: "[...] I was invoking Allah when I was overwhelmed by sleep. I had a vision in which the noble person of the Prophet blended with my own self to such an extent that we became a single being: I looked at myself and I saw him, transformed into me."25 In the mawqif 83, the Emir describes several encounters with the Prophet first hearing him, and later seeing him. The first word he received from the Prophet once he had arrived in Medina and was standing in front of the Rawdia was: "Thou art my son and I am satisfied with you!"26 Since at least the time of 'Abd al-'Azīz al-Dabbāgh (d. 1717), then of Tijānī and Aḥmad b. Idrīs, fāsī Sufism was characterised by a direct attachment to the Prophet. Ruggero Vimercati

$24 T a$ siss I, p. 19 There are two versions of the $T a$ 'sis. The first was published by Layachi Serbout, the owner of Qandūsīs autograph manuscript; this version was completed in $1252 / 1837$, in the month of Dhū al-qā̄da. The title it was given is: al-Ta’sīs fì al-madākhil 'alā masāwì al-dunyā wa-mahāwì Iblìs. The publisher established the text and initially printed it on demand, under the title of Satan Tools against the religion of Allah. Qandūsì's name does not appear on the cover, only inside the cover. Despite this lack of academic rigour, which diminished the visibility and distribution of the book (we have observed that the title has since been withdrawn from the site in question), the text is correct, and is accompanied by numerous explanatory notes on the author's vocabulary and dialect; it also contains images from the autograph manuscript, and these make it possible to establish its provenance. A second manuscript of the Ta'sis is preserved in the National Library of Rabat, shelved under $2526 \mathrm{~K}$; this has the title al-Ta'siss fi masāwi al-dunyā wa-mahāwi Iblīs. This copy was created in 1255/1840 during the master's lifetime, by Muhammad 'Abd al-Salām al-Ghumārī. It is considerably longer than the original 1252/1837 version, which probably means that Qandūsī dictated the Ta'siss, and made commentaries on it to his disciples. In addition, the contents of this second version are sometimes less clear. We will call the first version, from 1252, published by Serbout, "Ta'sīs I", and we will refer to the version copied by Ghumārī in 1255 only where it contains material that is absent from the autograph text. We will call this second version "Ta'sīs II".

25 Chodkiewicz, Écrits spirituels, $163^{-6}$.

26 Anta waladì wa-maqbūl 'alayya, Jazāinīi, Kitāa al-mawāqif, 1: 16o. 
Sanseverino has studied the relationship between this phenomenon and the foundation of new spiritual Paths. In the cases of the Emir and of Qandūsī, the Prophet's intervention is not linked to the establishment of a "Muhammadan" order; nevertheless, Qandūsì's Prophet-oriented Sufism is part of the history of the Țarīqa muhammadiyya. Vimercati recalls Abū Sālim al-'Ayyāshī's (d. 109o/1679) definition:

It is called al-Muhammadiyya because of our lord Muhammad, may salvation and the peace of God be upon him. It is special because of the attachment to him, even though all the Paths come from him. The adept progresses through his rectitude and in conformity with the Qurān and the sunna, and through the fact of his devotion to the prayer on the Prophet until love for him takes possession of the adept's heart, and his entire conscience is submerged in veneration for him. Then he trembles when he hears [the Prophet's] name, and the vision of the Prophet takes over his heart; the Prophetic form (mithāl) then appears before his inner eye, and God fills him with His interior and exterior blessings. He ascribes no merit to any creature but the Prophet, and sees him when awake as much as in dreams, and asks him for what he desires. ${ }^{27}$

Please note that Qandūsī himself ended his second copy of the Ta'sis with a reflection on the Muhammadan Path. He speaks of his treatise as "this noble Muhammadan flow" (hädhā al-fayd al-sharîf al-muhammadī). The Ta'siss carries the Muhammadan stamp, that:

Stamps with its seal $\left(t \bar{a} a i^{\prime}\right)$ everything that it seals, but nothing can seal it. Its coin is pure gold and a crown decorated with diadems [...] The 'Muhammadan' station surpasses all other stations, its aspiration is Muḥammad, it sees only Muhammad, it desires nothing but Muhammad, it is annihilated only in Muhammad, its Paradise is Muhammad, its life is Muhammad, its food, its drink, its drunkenness and its sobriety are Muhammad. ${ }^{28}$

27 Vimercati, "Penser la voie muḥammadienne", 122. For more on the Țariqa muhammadiyya, see the historic overview in Chih, "A New Historiographical Outlook on the Taríqa Muhammadiyya", in J. Malik and S. Zarrabi-Zadeh, eds, Sufism East and West: Mystical Islam and Cross-Cultural Exchange in the Modern World, Boston - Leiden, Brill, 2019, 104-126.

28 Fa-țuruqāt hādhihi al-risāla țābi'uhā muhammadīyațba'u kulla țābi'wa-lā yuṭba'u 'alayhi, fa-sikkatuhā ibrìzan wa-tājan mukallal [...] fa-maqāmu al-muhammadì a'lā wa-a là fahimmatuhu Muḥammad wa-lāyanz̧uru illā Muhammad, wa-lā ishquhu illā fì Muhammad, 
Let us return to Qandūsīs reasons for settling in Fez. In the 1899 codex in the National Library of the Kingdom of Morocco there is an autograph page by Qandūsī, published by Ḥammādī, in which he recounts the following:

When I entered into the Holy Idrisid Presence(al-hadra al-idrisiyya, the town of Fez) - may peace, mercy and God's blessing be upon it and on its inhabitants! - after a period of wandering and privation (siy ăha wa-tajrìd) that led me to decide to visit [Moulay Idrīs II] in order to go to the Home of God and seek shelter and refuge there, [then] on behalf of my Master [the Prophet] - peace be upon him! - I received direct permission to remain in the presence of the Sultan of the people of God, Moulay Idrīs - may God be satisfied with him, and with us through him! - in the supreme service of God (al-jānib al-'alì bi-lläh). My Master assured me that I would obtain the divine grace that I was seeking, which is granted to the pilgrim who decides to remain in the Temple of Mecca. He also assured me that this reward was reserved for me, by his side. So I obeyed the order. I was then given permission to marry and to work as a seller of herbs in the souk. And then I married according to the sunna of God and his Prophet $[\ldots]^{29}$

We know little about Qandūsìs life and training before he arrived in Fez. An autobiographical note contained in BNRM $1688 \mathrm{D}$ is, however, eloquent on how he had amassed his esoteric knowledge on the personal realisation of Muhammadan Reality. After having acquired the science of Letters from his masters, Qandūsī recounts having been "taken away" ( jadhb) from this science by God, through the Prophet, who drew him into the science of Absolute Unity ( ilm al-wahda), steeped in the Reality of Muhammad:

I rid myself of all other knowledge beyond this one, I wanted nothing else in its place, nevermore did I turn towards the applications [of the science] of names since the theophany of the essence of the Named One. [...] Everything that is not the source of Muhammadan essence is but an outer crust (qishr). Since God plunged heart, intellect, and spirit in the direction of the Well-beloved Lover, Peace and blessings upon him, the

wa-lā yafnā illā fì Muḥammad, fa-jannatuhu Muhammad, wa-ḩayātuhu Muhammad, waakluhu wa sharābuhu wa-sukruhu wa-șaḥwhu Muhammad, Ta'sīs II, fol. 159b-16oa.

29 MS BNRM 1699 D, fol. 1a, passage published by Ḥammādī, Fayḍ, 63. The passage continues with a list of his children and his wives, with dates of birth and death; a number of his children died when they were very young. 
secret of his reality shines brightly on the essence of my reality; thanks to this, God has made me so that I need no other but him (aghnāni bihi 'an ghayrihi). [...] Muhammad is our Prophet and the essence of our first original determination (ta'ayyununā al-awwal al-așlì), the substance of our primordial matter (hylé, hayūla $)$, the flood that overflows from the Holy presence of our Lord through the intercession of His first original determination [...] in us he is the first, the last, the apparent, the hidden, it is he who brings about his own epiphany in us. In our hearts, God mentions nothing except Muhammad; no one other than Muḥammad adores God in our primordial matter (hylé). Nothing stirs in us except Muhammad, all that rests in us is only Muhammad. All that thine eyes can see, of that of which God has determined the existence, proceeds only from Muhammad, whether through uniting or separating. ${ }^{30}$

After this passage, the initiatic journey is described as a voyage through symbolic letters to discover their kernel, which is "the Master", the Prophet:

O thou who wanderest on earth, on sea and in deserts, the earth and the sea are within thee! Travel through thine earth and sea, board the vessel of thine ocean, thou shalt find in thyself that which will guide thee, thou carryest in thyself the pearl and the hyacinths, the pure gold, the antimony, the coral, thou hast Paradise and Inferno within thee, soul's desire and eye's delight. Cease being ( $z u l$ ' $a n k a$ ), thou shalt see thine earth and thy sea, thou art thine own veil, correct the letter of thy nūn ${ }^{31}$ if thou desirest thy grace, set thyself in motion, lower thy voice. The one whose being has truly been absorbed is the one who has made the reality of his letter nün disappear, who has fathomed his earth as well as his sea, and has resolved the enigma of his manifest form - the one who has broken its crust and eaten its kernel. Thy crust is the letter of thy nün and thy kernel is thy Master, the letter $h \bar{a}^{\prime}$ of thine end (intihäuka). The letter $h \bar{a}^{\prime}$ cannot be found unless the letter nūn disappears. Thy $h \bar{a}^{\prime}$ is thy treasure, the $n \bar{u} n$ is thy veil, the $n \bar{u} n$ is thy passion, the $h \bar{a}^{\prime}$ thy secrets, the nün thy fire, the $h \bar{a}$ thy Paradise, the $n \bar{u} n$ is thine external form. The $h \bar{a}$ is thy life, the nūn is thy soul's aspect (nafsāniyyatuka), the $h \bar{a}^{\prime}$ thy spiritual aspect,

30 MS BNRM $1688 \mathrm{D}$, Taqāyid, 7 (from the pdf furnished by the library). This is a collection of Qandūsì's writings, notes and more polished texts. The page in question is numbered "fol. 3 ", but it is not the third one in the collection; we were unable to consult the codex in question directly. 
the $n \bar{u} n$ is thine earthly kingdom, the $h \bar{a}$ thy celestial reign, the $n \bar{u} n$ is thy night, the $h \bar{a}^{\prime}$ thy day, the $n \bar{u} n$ is thy sight, the $h \bar{a}^{3}$ thy clairvoyance, correct thy gaze, open thy clairvoyant gaze! Leave the earth and travel in thy heaven, be like a celestial bird $[\ldots] .^{32}$

Fez remained the site of Qandūsì's "simple" life as a seller of herbs and calligrapher. This was the town of Moulay Idrīs, to whom he vowed a particular devotion - as an autograph poem demonstrates. ${ }^{33} \mathrm{He}$ must have been writing his works during much of the time he was in his shop (he produced nearly two thousand folios; these haven't yet been systematically recorded). At the end of his Ta’šs he himself says:

O thou who shalt find this document, to whom God has granted clairvoyance! If thou seest errors therein, correct them! The unlettered one has a great many excuses, he knows no part of the external sciences, and still less of grammar! [...] The state of the reunited opposites, the physical and the intelligible, is very subtle [...] I have composed this book in the herbsellers' souk, where I buy and sell to earn my living. I write, and a client comes to me and asks for a dirham of absinthe, of thyme, of fenugreek, of nigella. So then I put down the page, I serve the client, then I return from [the world of] the senses to [that of] the spirit, for if it hadn't been through God's power I could never have written a single word on my own, because bringing opposites together is difficult, and opposites can only be united with the support of God and his Envoy ... This is something that is well-known among the masters and the initiates (al-qawm), that the spiritual sense is like a bird; as soon as something from the world that we apprehend with our senses disturbs it, it quickly flies away ...34

Writing is the fruit of divine inspiration, and of spiritual support from the Prophet, as Qandūsī avers in another collection of various notes: "All of the essential truths (haqāiq) contained in this blessed collection come directly from the inspiration that God has granted us and from the support of my Master, peace and blessings upon him, and the same is true of all our other works." ${ }^{35}$ The souk is also a place where the Prophet - Qandūsìs interior

32 Ta'sīs I, 19-20.

33 MS BNRM 2127-2 K fol. 15 a (l. 1 of the poem): "a-mawlāya yā Idrīs [...]".

34 Ta'sīs I, 297-298.

35 MS BNRM 1688 D, Taqāyìd, 10 (from the pdf): "wa-kullu mā hunā min al-haqā̄iq fi hādhā l-majmū' al-mubārak fa-kulluhā min fatḥ Allāh 'alaynā wa-madad sayyid̄̄ wa-kadhālika kullu mā lanā min al-ta'ālìffì ghayrihi". 
Prophet - can manifest himself and come to meet our author. A personal note relates his waking encounter with the Prophet:

After having said my afternoon prayer, I was sitting in my stall in the herb sellers' souk. I was seized by a state that was imperceptible to all others. Therefore, seized by such a state, I rose and left my shop to go to the great mosque, I mean the Qarawiyin, without even perceiving that I had been seized. I found him [the Prophet] - peace and blessings upon him - seated with the four Caliphs - may God be satisfied with them, ammin! - So I sat down facing him, and he said, "From me and for me! (minnī ilayya)" [...] From him I received the prayer of the Divine Essence (al-șalāt al-dhätiyya). He said to me - peace and blessings be upon him "Repeat this:

O God, grant thy uniting grace to the resplendent, essential, perfect light, the secret of which circulates within existence. ${ }^{36}$

He repeated this phrase three times, and I in my turn recited it three times while he listened to me. He told me: "I have established thee in the Station of the Choice (maqām al-takhyir); if thou desirest to speak, speak, if thou desirest to remain silent, remain silent. [...]." I remained there, sitting with him until the call to the sunset prayer, then I rose to pray with the men $[\ldots]$. He went out with his companions. His Noble Image (șüratuhu al-sharīfa) stayed with me until I performed the night-time prayer $[\ldots]^{37}$

This "resplendent light" mentioned above is the form in which Qandūsī perceived himself during his Ascension (described above). Without saying so explicitly, he identifies with the Prophetic manifestation. Another manuscript bears witness to Qandūsī's attachment to this prayer received directly from the Prophet. In a commentary in which Qandūsī explains his ties of love with the Prophet, he writes: "When thou sayest ' $O$ God, grant thy uniting grace to the resplendent, essential, perfect light [...]', this light is a pure love, the contemplation of which plunges thee into a direct vision of the well-beloved until thou seest the beauty of everything that exists, included within his Presence

36 Allāhumma șalli 'alā al-nūr al-șâtii, al-dhātī, al-kāmil, al-sārī sirruhu fí al-wujūd. This formulation has similarities with a prayer attributed to Abū al-Ḥasan al-Shādhilī, which is itself attested with numerous variants: Allāhumma șalli wasallim wa-bārik 'alā sayyidinā Muhammad al-nūr al-dhātī wa-al-sirr al-sārī fì sā'ir al-asmā' wa-l-șifāt. See Nabahānī, Afḍal șalāwāt, 113-4. See also Le Baot, "Quelques variants". 


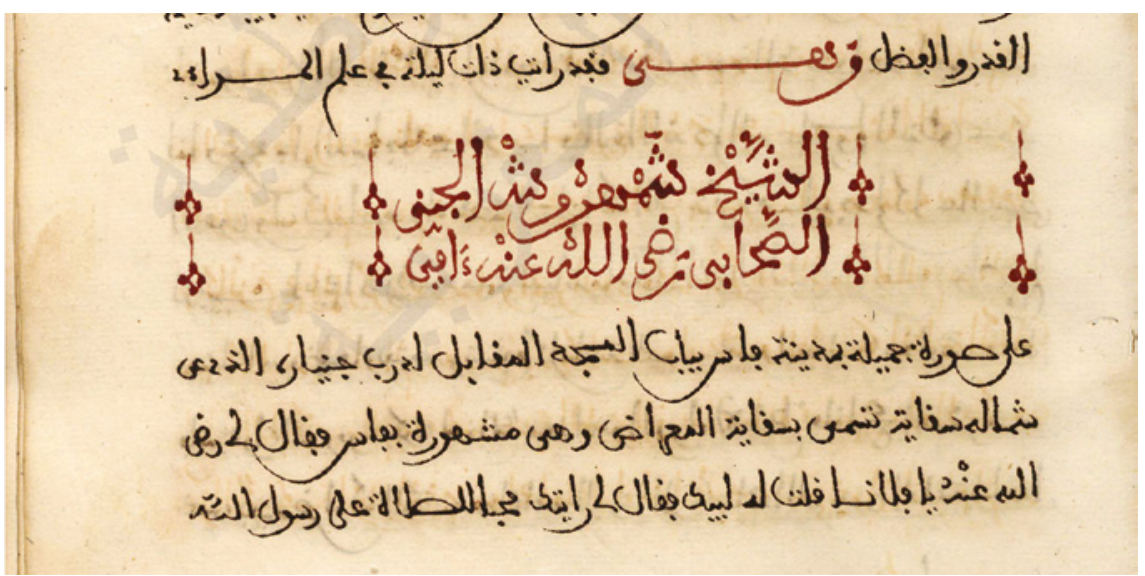

FIGURE 20.2 Ta'sīs II fol. 77a. The encounter with Shamharūsh

and never separate from it, because it encompasses the whole." ${ }^{38}$ In the manuscript this vision is followed by a second account: Qandūsī relates that one of his acquaintances, the brother in God, the sayyid, the faqir Ahmad b. 'Abd al-Raḥmān al-Qandūsī ${ }^{39}$ came to visit him while he was asleep in the morning after sunrise, and announced to him "Be aware that my Master - peace and blessings be upon him - has sent me to bring you the good news that while you're awake you will meet him!' Qandūsĩ confirms that he met the Prophet again in the Qarawiyinn, in the mihrāb.

Fez is also the setting for another extraordinary visionary encounter, with the long-lived jinnī Shamharūsh (Figure 2), who met the Prophet Muhammad in person and, because of this, is a șahābi..$^{40}$ Let us note that (in the copy of the Ta'siss made by Ghumārī) the jinnìs name is richly calligraphed and detached from the rest of the writing. This graphic process highlights the passage into a parallel world:

38 fa-kāna hādhā al-nūr ḥubb maḥ fa-innahu yastaghriquka shuhūduhu fí mushāhadat jamāl al-maḥbūb hạattā tarā jamāl kull mawjūd mundarij fïhi wa-lam yabraḥ min ḥaḍratihi fa-qad hawā al-kull fa-fham. This commentary is called al-nür al-säți 'fí l-ilm al-näfi', and is at the beginning of codex $2135 \mathrm{~K}$, which also contains another treatise by Qandūsī, the Bawāriq al-ahmadiyya fi l-haraka wa-l-suküniyya. The passage cited can be found in folio 1a. Abdulaziz Suraqah furnished the transcription of this text.

39 It would be useful to undertake further research on the presence in Fez of people from al-Qanādisa.

40 This jinnī's nature, role and function have been discussed in several classical sources. See Hammādī, Fayḍ, 57-63 for an overview of this literature. The cave in which Shamharūsh died, on Mount Toubkal in the Moroccan Imlīl region, is much visited; see Maarouf, "Saints and Social Justice in Morocco". 
One night, I saw in the specular world (al-älam al-mirā̉̄ the Master Shamharūsh the Jinn, the Prophet's Companion, in a pleasant form, in the town of Fez near the entrance to the mosque that is in "Janyāra" street, to the right of the fountain called the mi' ră, , which everyone in Fez knows. ${ }^{41}$ He addressed me: “O thou!"; “Here is where I am!", I replied. He continued, "I see that thou lovest to pray on God's envoy, therefore I wanted to grant thee a privilege that springs from his grace, and that I have never granted to anyone else except for the shaykh Tāwdī b. Sūda, ${ }^{42}$ who received it from me, and I wish to transmit it to thee as well. Except for the two of you, no one has received it from me since I received it directly from the Prophet. Here it is: One day I was speaking with the Prophet - peace and blessings be upon him - about the merits of prayer. He asked me, 'If a man has been written down as damned even in his mother's belly, is there any remedy for his damnation?' I replied, 'God and his Prophet have greater knowledge!' [The Prophet] continued, 'If the man has been written down as damned even in his mother's belly, and he is born into the world and engages in praying upon me, this request for grace will transform his damnation into bliss in the Hereafter. ${ }^{43}$

Qandūsî's visions must have been numerous; for example, he recounts having suffered unbearable pain from an abscess in his jaw, near his temple. He was obliged to stay in bed, not eating or drinking except for a little bit of soup (harira). Then he turned away from the physician:

I concentrated my energy on the freshness of my eyes, he who is the supreme doctor (al-tabib al-azam). The bitterness of pain was softened until I could no longer feel it. Then the Master of Existence came to me after I had said the night prayer, when I was lying on my bed half asleep (but more awake than asleep) [...] I saw him in front of the bed on which I lay, seated facing me. He spoke to me - peace and blessings upon

41 We have been unable to identify this place.

42 Abū 'Abd Allāh al-Tāwdī b. Sūda (d. 1209/1794) directed a Nāṣiriyya zāwiya in Fez (see Vimercati, Fès et sainteté, chapter entitled "Le savant et imām de la communauté", online at https://books.openedition.org/cjb/538). Other sources tell of the transmission between Ibn Sūda and Shamharūsh, see Kattānī, Sharh al-shamā̉il al-muḥāmmadiyya, 64 n. 3. 'Abd al-Hayy al-Kattānī lays claim to a chain of transmission related to the way the Prophet put on his turban, which goes back to the Prophet through Shamharūsh. The note mentioned above contains a long biography on the role of Shamharūsh as a transmitter of hadith. Most of its sources date from the eighteenth century.

Qandūsī, Ta’sis I, 79; Ta’sis II, fol. 77a. 
him - 'God will heal thy pain in an instant, by His strength and His power.' [The Prophet] took an instrument [...] of light out from under his cloak and asked me to open my mouth. ${ }^{44}$

Another very sacred place in Fez, Bāb F'tūh cemetery, is also mentioned in Qandūsì's manuscript notes. He claims to have received a special type of prayer on the Prophet "in the presence of the people of God, in Bāb F'tūh, in Fez, in the morning of Friday, the seventh day of the month of Muharram 1274/1857". This prayer is a variation on the Prayer of "Divine immensity" (al-șalät al-'azimmiyya) transmitted by another master from Fez and a contemporary of Qandūsì's, Aḥmad b. Idrīs (d. 1253/1837).45

There are several remarkable elements in these accounts, only parts of which we have translated. First, they confirm the concealed nature of Qandūsi's states. The notion of love is also central. The life of the master from the herb sellers' souk is governed by this reciprocal bond of love and desire between himself and the Prophet. Qandūsìs accounts of his visions (in a wakeful or in a sleeping state) end with a short note on a period of three consecutive months during which he lived in an intoxication of ecstasy that led him to contemplate the Prophet in himself. However, he cannot and will not recount what he experienced, for the men of his day are no longer suited to receiving such inspiration. ${ }^{46}$ Taking up a theme that is very old, but is strongly re-affirmed and actualised by our author, he observes that now and henceforth God has veiled the hearts of mankind, preventing them from knowing holiness: "the greatest of saints live among them, but men do not perceive them." 47

An apparent contradiction attracts our attention. Qandūsĩ declares himself to be a descendant of the Aws, but at the same time the Prophet apparently confirms that he has Sharifian ancestry (anta waladi haqqan, in the Ta'siss;

44 Qandūsī, Ta’sīs I, 10o; Ta’sīs II, fol. 94a.

45 Allāhumma șalli 'alā sayyidinā Muhāmmad haqqa qadrihi wa-miqdārihi wa-khalqihi wa-khuluqihi al-'ażìm wa-'alà ālihi wa-ṣaḥbihi wa-sallim. Qandūsī adds: Wa-hiya miftāh al-qalb al-muzlim lam tazal taftaḥuhu min aghlāqihi ḥattā taftaḥahu fat'han mubinan wa-tamla'ahu nüran wa-sirran ka'anna șāhibahā [...] tuftaḥu lahu abwāb al-janna al-thamāniya yadkhulu min ayyihimā (sic) shä'a. Wa-tarfáu qadrahu wa miqdārahu wa-tahsunu khuluquhu wa-khalīquhu hisssan wama 'nan wa-Allāh dhü l-faḍl al-'ażìm. Ms BNRM 1688 D, Taqāyìd, 10 (from the pdf).

46 Wa-ammā al-mushāhada fiyya lahu - șalla Allāh 'alayhi wa-sallam - fì hāàl sukr alladhī kuntu fìhifì (...?) fì thalāthat ashhur min rajab ilā ramad̄ān wa-anā fíal-sukr fìi, fa-dhālika lā yalīqu wa-lā yufshā li'anna al-qulüb fìzamāninā hādhā jubilat 'alā al-inkār wa-l-hirs [...], Ms $399 \mathrm{~K}$, fol. $7 \mathrm{~b}$.

47 Hattā a'mā Allāh quī̄bahum 'an ma'rifat al-awliyā' al-kibār wa-hum bayna az̧hurihim wa-lā shu'ür lahum bihim, ms $399 \mathrm{~K}$, fol. $7 \mathrm{~b}$. 
minnī ilayya, in this last passage). Hammādī says that the Kattānī are wrong to think that Qandūsì is a sharīf. In fact, his fusion with the Prophetic being goes beyond the question of genealogy. At heart, by affirming that Qandūsì is of him and returns to him, the Prophet is referring to the doctrine described in the $T a$ 'siss, according to which everything comes from the metaphysical reality that is the Prophet. These encounters are moments of full realisation of this elective and ontological bond. Qandūsì's Sufism is a path that blends art, devotion to the Prophet, and esoteric sciences behind the veil of the simple life of a shopkeeper in the souk. We have already observed how this occultation in the eyes of other people is wished for by our author. He also emphasises that he moves in the circles of trades and corporations. Qandūsĩ draws on the life of a small shopkeeper in the souk for his metaphors and symbols, and for the advice he offers. For example, in a passage in the Ta'sis he asserts that the master craftsman (mu'allim al-șan'a) benefits from an initiatic secret comparable to that of the spiritual master. The apprentice's mastery may go beyond that of the artisan, just as the disciple's spiritual degree may outstrip the master's. ${ }^{48}$ The reasoning behind this analogy once again goes back to the ontological "first determination" that is Prophetic reality. Specifically, Qandūsī refers to "the derivation of secrets and light's penetration" (ishtiqua q al-asrār wa-infilāq al-anwār), the expression with which the Salät mashishiyya begins. ${ }^{49}$ Different trades and occupations draw their secrets from this initial division of the original secret, the Prophet's secret; he is the "primordial handful" (qabda).$^{50}$ The Sharāb ahl al-șafā is a little manual composed by our author, in which he proposes an original method for practising the prayer on the Prophet (al-șalāt 'ala $a l-n a b \bar{\imath})$; this requires one to transform all of life's events numerically into a specific number of prayers on the Prophet. For example, he advises readers to change the price of a purchase or the address of a shop into a corresponding number of prayers in order to receive the Prophet's blessings. ${ }^{51}$ This path is evidently rooted in Qandūsì's surroundings and class, although the notables of his time also associated with him. The Vizier Idrīs b. Idrīs, of whom we will speak in the second part of this chapter, commissioned from him the great Qur'ān in twelve volumes. Al-Manūnī says that Qandūsī corresponded with the governor ('āmil) of Fez, Idrīs b. 'Abd al-Raḥmān al-Sarrāj al-Ḥumayrī (d. 1887/1304).

\footnotetext{
48 Qandūsī, Ta’siss I, 168.

49 For more on this prayer, attributed to the Moroccan master 'Abd al-Salām b. Mashish (d. 625/1227), see Hamidoune, La pratique de la "prière sur le prophète" en Islam, p. 302.

50 wa-aṣl dhālika kulluhu ma'khūdh min ishtiqāq al-asrār wa-infilāq al-anwār min al-qabụda al-muhammadìya wa-sāra sirr dhālika fi furū‘ hayākil min șinā'āt al-zāhir wa-al-bāțin, Qandūsī, Ta’siss I, 168.

$5^{1} \quad$ Qandūsī, Sharāb ahl al-șāāā, 37 and subsequent.
} 
This correspondence is said to have been collected by Qandūsì's disciple, Vizier Muḥammad b. Aḥmad al-Ṣanhājī al-Fāsī (d. 1891/1309), who offered Qandūsī the title al-Fatḥ al-quddūsìfi-mā fäḍa bihi SayyidīMuhammad al-Qandūsī. This text is said to have been found in the possession of a family from Marrakesh, but we do not know its present location. ${ }^{52}$ However, the attribution to Qandūsī of the $i j \bar{a} z a$ in the Dalāil given to Sultan Moulay Sulaymān b. Muhammad is not authentic; Qandūsì's name does not appear anywhere in this work. ${ }^{53}$

Finally, the emphasis on the form adopted by the Prophet (a white pearl, or simply the "noble image", suuratu-hu al-shariffa) is linked with the efforts Qandūsī invested in retransmitting these images through his manuscripts, and in his symbolic designs (graphics, graphemes, calligraphic style). It is through this visual and aesthetic fusion that the link between the spiritual master and the master calligrapher is created. In the next section we will examine a number of important passages.

2

\section{Making the Prophet Visible: Calligraphy as a Means of Spiritual Realisation}

The first text we will examine is quoted at the head of this chapter, and it defines the "universal mirror" (mir'ät al-kull), an absolutely pure surface that is the origin of everything and towards which every image returns by refraction. This way of presenting the haqiqa muhammadiyya is both well-established in Maghribi Shādhili Sufism (we have mentioned its expression in the opening of the salät mashishiyya) and also very personal, for it springs from the "visionary" sensibility of a calligrapher. Qandūsī demonstrates this great sensitivity to forms in his best-known works: his monumental Qurān and his copies of al-Jazūlì's Daläil al-Khayrāt are those that we will examine here. Let us take as an example the name of the Prophet and its link to the name of majesty, Allāh. Ghumārin's copy of the Ta'sis contains a passage on the esoteric meaning of the grapheme "Muhammad". As with the encounter with the jinn Shamharūsh, the writing in this passage changes its appearance and the name of the Prophet, the tetragram "Muhammad" (Figure 20.3), is highlighted in red. This passage describes the nobility of the human being, whose physical form derives from that of the name Muhammad. Qandūsī goes further. By transforming

52 Manūnī, al-mașādir al-'arabiyya, 2: 134, cited by Hammādī, Fayḍ, 85 .

53 The catalogue of the National Library in Rabat refers to this as a work by Qandūsī; MS 2795 D, fol. 361a. 


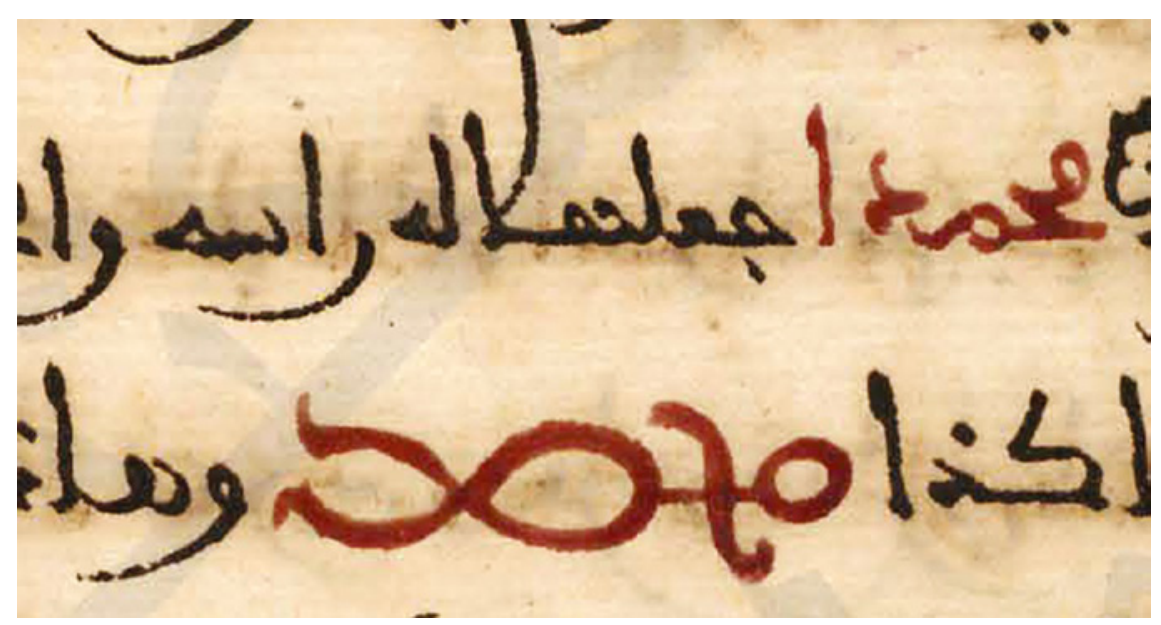

FIgURE 20.3 Ta'sis II, fol. 83a. The tetragram "Muhammad"

the letters, he relates the name Muhammad to the name Allāh. To differing degrees, all existence derives from the name "Muhammad":

The name Muhammad comes from the Name of majesty, "Allāh". The tail comes from the alif, for humans have a tail like all the other animals, but it is not apparent, because this makes [humans] look more perfect. The two arms and the two legs come from the two lāms. The letter $h \bar{a}$ ' is the head. The Name of majesty is made manifest in the form of the name "Muhammad". It also appears in the fingers of the hand $[\ldots]^{54}$

Beings come from the letters of the name Muhammad. Some of them come from the $h \bar{a}$, some from the double mim, some from the $d \bar{a} l$, some come from two letters and some from three. Human beings come from the four letters, because God linked Adam and his descendants to His Well-Beloved Muhammad. ${ }^{55}$

This quest for understanding through the realisation of the superior meaning of the name of the Prophet is also at the centre of Qandūsi's Sharāb. In this text he transmits his particular understanding of the Qurānic verse "To God belong the Names Most Beautiful" (Q $7: 180$, Arberry): 
If we enlarge our reflection on this noble verse we observe that its ocean is immense and takes in not only the 99 names of God related by tradition (al-wärida). In reality, grace attains the name by which the 100 names are completed, and that name is the name of His well-beloved Muhammad, peace and blessings upon him! - for the name of His wellbeloved is never separated from the name of God. [... $]^{56}$

He who knows the name of Muhammad - peace and blessings upon him! - in its essence and not merely by its attributes knows the supreme name of God, for the name of the well-beloved is the essence of the divine names [...]. For he who invokes God by the name of His well-beloved peace and blessings upon him! -will see his prayers answered. ${ }^{57}[\ldots]$

The names all together are the name of the well-beloved, and the name of the well-beloved is the supreme name of God. ${ }^{58}$

From this realisation of the name of God is born a particular method for the practice of the prayer on the Prophet, which we have mentioned above: each moment of daily life can be linked to the name of the Prophet through a numerical calculation and a specific number of prayers. This "union" between the names of God and of Muhammad is explained masterfully by Qandūsī in a special prayer called "The Great Elixir". Its opening lines refer again to alchemical elements already mentioned in an autobiographical passage on the realisation of the inner Prophet:

O God, grant Thy uniting grace, Thy salvation and Thy blessing to the one in whose name Thou hast poured the ambrosia of Thy supreme name Allāh, our master Muhammad, God's Envoy! These two noble and majestic names were exalted above all other noble names. They are the root of every branch, the quintessence of every essence, the supreme wine of all wines, the secret of every secret, the knowledge of all knowledge, the wisdom of all wisdom, the light of all lights, the elixir of all elixirs, the alchemy of all alchemy, the red sulphur of all red sulphurs, the theriac of all theriacs, the magnet of all magnets, the antimony of eyes, the hyacinth of all Brahmanic hyacinths, the pearl of all pearls, the jewel of all jewels, the gem of all gems, the carnelian of all carnelians, the coral of all corals,

56 Qandūsī, Sharāb, 27.

57 Qandūsī, Sharāb, 29.

$5^{8}$ Qandūsī, Sharāb, 3o. In the Ta’sis Qandūsī also refers to the name Muhammad as the one-hundredth divine name after the ninety-nine names in the Tradition of the 99 Divine Names; Ta’sis I, 289 . 
the peridot of all peridots, the pure gold of all pure gold, the pure silver of all pure silver, the silk of all silks, the brocade of all brocades, the musk of all musks, the camphor of all camphors, the perfume of all perfumes, the fragrance of all fragrances, the balm of all balms, may God grant him His uniting grace and salute him, along with his family.

O God, grant Thy uniting grace, Thy salvation and Thy blessing on he whose name, Ahmad, you have steeped in the secret of Thy name, the All-Merciful, through Lā ilāha Illā llāh Muhammadun rasūl Allāh. ${ }^{59}$

The bond between God's name and the Prophet's, and the anthropomorphic form of the latter, are ancient themes, which can be found, for example, in the Sharaf al-Muștafā, by Khargūshī, a Nishapurian master who died in 1015-16. Khargūshì devotes a chapter in his book to the question of the Prophet's names, and maintains that the name "Muhammad" derives from the praise-names "al-Ḥamīd" and "al-Mahmūd". Then he cites a poem that he attributes to Abū Taalib, which gives the impression that the privilege implicit in such a name was already evident when the Prophet was born: "In order to magnify him, God derived his name from His Name. The Master of the Throne is Mahmūd, and this one is Muhammad!" Then Khargūshī establishes a parallel between each letter of the name Muhammad and the human body. ${ }^{60}$ Much has been written about the relationship between the Prophet's names and those of God. 'Abd al-Karīm al-jīlì (d. 1424), in his Kamālàt, affirms explicitly that the name Allāh is the name Muhammad. Another, later, master of the Akbarian school, 'Abd al-Ghānī al-Nābulusī (d. 1143/1731), gives a detailed explanation in a text devoted to the esoteric explication of the "pillars" of Islam. In one chapter, he sets himself to explaining the inner and hidden meaning of the profession of faith: là ilăha illa llāh Muhammad rasūl Allāh. Although, according to external law, each part of the profession of faith has its own status and implications (divine unicity and affirmation of the prophecy), their true esoteric meaning is unique and indivisible: 61

God has made Muhammad manifest among us and Muhammad has likewise made God manifest among us, like the light that cannot be known

59 This extract was edited and translated by Suraqah, The Grand Elixir, 15-16. The Sayf al-ināya is made up of various chapters that bring together particular modes of prayer on the Prophet. The manuscript is preserved in the National Library of Rabat, shelved under $1699 \mathrm{D}$ (majmū̌ awwalu-hu taqālìd fí ism Allāh al-ałzam).

6o al-Khargūshī, Manāhil al-shifā, I, 69 .

61 Wa-ammā bayān al-hāqū̃qa fa-inna hātayn al-shahādatayn tadākhalatā bihaythu șāratā shahādatan wāhidatan wabaynahumā talāzum ma'nawī. 
without darkness, or shadows that cannot be known away from the light. For this reason, God states that "he who obeys the Envoy has obeyed God". [...] He who meditates will see that the whole universe is in accordance with the Muhammadan form and the word of majesty ('alä al-șüra al-muhammadiyya wa lafzat al-jaläla). If it was not thus, no superior reality could establish itself in this world, and for this reason those who held that "the name is the essence of the named" spoke the truth, for otherwise, if it was not its essence, the image of the named would not be able to impose itself in the heart of the person hearing the name. The entire world is the form of the name Muhammad and the form of the name Muhammad is the form of the name Allāh $[. . .]^{62}$

As well as casting light on the "genealogy" of a doctrine, in such texts it is also interesting to note what was unique to Qandūsī. And it is the graphic approach that is our master's defining quality. Although ideas around the esoteric ties between the divine and the Muhammadan realities, as made manifest in their names, are already present in earlier esoteric literature, Qandūsī realises these concepts through and in his calligraphy. One example of these ties is an introductory page preceding his personal copy of the Dāläil al-Khayrät, MS 399K, which we will shortly examine in greater detail (see Figures 22-27).

The border between being and writing is a subtle one; the calligrapher wants to become writing. In one passage in the $T a$ s'sis, the practice of calligraphy and the craft of the copyist become symbolic images of the spiritual master:

The spiritual master undoes the knots of the disciple's inner being (bawātin), he acts within him like a skilled copyist who perfectly masters the art of [resolving] difficulties around terms and letters, one letter at a time (harfan harfan). He knows how to open their hollow eyes (fath 'uyūnihā al-mujawwafa). ${ }^{63} \mathrm{He}$ knows which letter needs one dot, which other letter needs two or three dots. [He knows which letter] deserves to

62 al-Nābulusī, Asrār al-sharīa, 233-236.

63 Mujawwafa letters, which are rounded, have an "obscure" side - at least according to an imagined dialogue between this earthly world and the Devil, in the course of which the latter says, "On the day God created Adam and formed him from clay, I was overwhelmed by jealousy of him. I went towards this form [Adam] and I pricked it lightly in the middle with my beak, and I heard a sort of hollow sound ( $f a$-samitu hasissahā mujawwafatan). I realised that I had a way in to each letter that contains a concavity ( jawf). I penetrated the letters $t \bar{a}$ ', mim and 'ayn, and I cleaned them out; then a word appeared and I pronounced it. It was the name of all perdition for Adam and his descendants: tama , covetousness." (Qandūsī, Ta’sīs I, 255). 
be written in silver and which other deserves gold. Every shape has an intelligible meaning, willst thou understand this? Therefore, respect the holiness of the masters if thou desirest that thy writing be drawn in pure gold (dhahab ibriz). Do not stop short at the colours of the illuminations (zakhārif) until thou art written down in Gold, for [writing in Pure Gold] never fades and nothing can corrupt it. Therefore, be alert to the subtle art (tadqiq) of the master.

This is very far from being an abstract metaphor. It is important to note that Qandūsī never created the illuminations in his calligraphed copies; their appearance shows that they are someone else's work. Gold is used in them, but it is not applied by his hand. This transformation of the being into writing is what the calligrapher asks from God in prayers such as those we cite above. This identification of the body with the writing process recurs in one late passage in the $T a$ 'sis, in which the metaphor employed is that of writing out the Qurān on wooden tablets (lawh, pl. alwāh). This traditional method for the teaching and learning of the Qurān (in which passages are written, read, corrected and re-written by the students, and then erased to make way for the next passage), becomes the symbol of the purification of the body through the double labour of erasing and re-writing. In this passage the supreme master is the Prophet himself:

[...] Go find the master of the children at the Qurānic school, attach thyself to him and observe how he is with the children, how he educates them and how the children recite [the Qurān written down on] their tablets before erasing it. [Observe] how they erase the tablets, and how they rub the clay upon them, and how they dry them. [...] Imagine thyself as one of these children before the master. If thou dost not manage to imagine thy master, [know that] in fact he is the Prophet. Begin by reciting what's on the tablet, look with thine own eyes and recite [to thy master] what is written there $[\ldots]^{64}$

This passage carries on over several pages. As with the prayer of transformation presented above, for each part of the body Qandūsī describes the process of "reading" its contents to the master, and then the correction, the erasing and the final re-writing. The human being is re-written by the "Muhammadan ink".65

64 Qandūsī, Ta’sīs I, 215.

65 Wa-ma'nā hibrika alladhī tuktabu bihi ayḍan min al-midād al-muhammadī, Qandūsī, Ta’sis I, 219. 
In this section we are examining Qandūsì's calligraphic style in order better to understand the link between the spiritual conception of writing extolled in the texts and the calligraphic œuvre of the master.

Aside from his importance in Moroccan religious life, Qandūsī also distinguished himself through his calligraphic talent. In fact, he changed the premodern codes of calligraphy in the Maghrib. In his hagiographical dictionary, al-Kattānī briefly mentions Qandūsì's calligraphic works, including his copies of the Qurān and of the famous book of prayers on the Prophet, the Dalāil al-Khayrāt, by the Moroccan mystic Muhammad b. Sulaymān al-Jazūlī (d. 869/1465):

He had a particularly beautiful and well-made line, which he used when he wrote out several Daläil, and I was told that he had also written out a Qurān in twelve volumes that people say is unequalled anywhere on Earth. 66

Oddly, in spite of the exceptional nature of Qandūsìs art and of the innovations he introduced into the eighteenth and nineteenth century maghribi ways of writing, relatively few copies of works formally identified as being by him exist today. Equally, there are few writings in existence that give us information on his activities as a copyist, apart from the scattered remarks the calligrapher left in the margins or introductory pages of his manuscripts, and a few commentaries by hagiographers or modern specialists in Moroccan books. Among the latter, Fawzī 'Abd al-Razzāq ${ }^{67}$ and Muhammad al-Manūnīî mention a copy of the Qur'ān signed by the master's hand in 1266/185 ${ }^{69}$ and seven manuscripts of the Daläil al-Khayrät, some of which were made for the royal family. However, F. 'Abd al-Razzāq gives neither catalogue numbers nor the location in which the copies of the Daläil are preserved, while Muhammad al-Manūnī wrongly attributes to Qandūsī several copies of the Dalāil that are held in the Royal Library.

66 wa kāna lahu khaț̣̂u ḥasanun jayyidun, kataba bihi 'iddat al-dawālèl [Dalāil al-Khayrāt], wa-ukhbirtu anna-hu kataba mușhafan fì ithnay 'ashara mujalladan qīla an lā yūjad nażiruhu fì l-dunyā, Kattānī, Salwat al-anfās, III, 54 .

67 'Abd al-Razzāq, The Kingdom of the Book, 32.

68 Manūnī, Tarīkh al-wirāqa, 173-5.

69 This Qurān 12613 in twelve volumes, held at the Royal al-Hasaniyya Library of Rabat. 
In order to grasp Qandūsīs creative process, we have decided to limit this study to two copied texts signed by the calligrapher - these are representative of his art and yet they reveal two distinct approaches. The first manuscript, a Qur'ān in twelve volumes from the Royal Library in Rabat (reference 12613) was the result of an official commission, while the second, the Daläil held in the National Library of the Kingdom of Morocco under the reference 399K, seems to have been produced by the calligrapher for his personal use.

The Quraan 12613 was finished on a Friday at the end of the month of Shawwāl 1266/September $185^{\circ}$, in response to a commission from a certain Idrīs b. Muhạmmad Idrīs al-'Amrāwī al-Zammūrī al-Idrīsī (d. 1295/1878), as the colophon at the end of the twelfth volume states (ff. 138a-138b). The patron is not unknown to us: he was a scholar and diplomat in the service of the Makhzen and came from one of the grandest families of Fez. Born in 1208/1794, he was the son of Muhammad b. Idrīs al-'Amrāwī (d. 1263/1847), who himself became the personal secretary of the Alawite Sultan Mulāy Muhammad b. 'Abd al-Raḥmān (r. 1238-1276/1822-1859). As early as 1277/186o, Idrīs b. Muhammad b. Idrīs al-'Amrāwī was Minister of Foreign Affairs under the reign of Mohammed IV (r. 1276-1290//1859-1873); the following year he was sent as the Sultan's emissary to France, in order to report back on the progress of modernisation at the time of the industrial revolution. He spent some time in Paris, and visited the Château of Versailles, the Paris Mint, the National Library and the official printing works of the French Government. In his report on the journey, Tuhfat al-malik al-'aziz bi-mamlakat Bariz (The Jewel of the well-beloved King in the Kingdom of Paris), ${ }^{70}$ he devotes several pages to the printing press, which he sees as one of the French technological advances that could profitably be developed in the Sharifian Empire. ${ }^{71}$ At the same time, he was also worried that such technological progress could not be adapted to an Arabo-Muslim society. His account of his trip does reveal that in spite of his strong attachment to local religious traditions, al-'Amrāwī felt a certain attraction to modernity.

70 Published in 1909, the account of the journey has been translated from Arabic to French by Luc Barbulesco under the title Le paradis des femmes et l'enfer des chevaux: relation du voyage d'Idriss al-Amraoui à Paris.

71 Barbulesco (tr.), Le paradis des femmes, 6o-65. When he returned to Morocco, al-Amraoui proposed the idea of installing a printing press to the Alawite Sultan, thus bringing about the creation of the country's first printworks in 1864 . "On our part, we pray to God that he should inspire Our Majesty, the Commander of Believers, to endow Morocco with such a printing press, and thus to add to the number of its benefits. He has already left signs of his generous actions, may he thus give new strength to religion and follow in the footsteps of the great Imams. Ámin." 
This makes it easier for us to understand why such a dignitary, close to the Makhzen, would want to acquire a manuscript of the Qurān from Qandūsī, whose style he must have recognised and appreciated as being singular and innovative for the period. As the calligrapher says in the colophon, the Qurān was finished in 1266/1850, about ten years after al-'Amrāwī's departure for France in spring 1277/186o. The quality of its execution is remarkable, both as regards the materials used for its illuminated decorations and for the originality of its calligraphic style. Each of the ten volumes still preserved at the Hasaniyya ${ }^{72}$ opens with a double page of text, the treatment of which is distinguished not only by its thick and mannered writing in a style unique to Qandūsī, but by the illuminated decoration that frames the text (Figures 20.14-16). It was usual in Qurānic manuscripts over several volumes to insert an ornamental and calligraphic accent in the first double page spread of each section. ${ }^{73}$ In Qandūsì's pages the writing, despite the monumentality and excessive thickness of the line, has a fluid vibrancy as a result of the shifting balance between the thickness of the letters and their slender, very sinuous tails. In order to achieve this effect, Qandūsì traced the outline of the letters, and their tails, with a fine black quill, and, very certainly, painted in these outlines with a pointed brush (Figures 20.4 and 20.5). This technique is uncommon in Maghribi manuscripts. It can be found for much earlier periods in the Muslim West, and was used to remarkable effect in the famous "Nanny's Qurān" (Mușhaf al-Hāḍina) copied in 410/1019-20 ${ }^{74}$ by the nanny of the Zirid Emir al-Mu'izz b. Bādis (r. 407/1016454/1062), in which the entire text has been traced according to this process. ${ }^{75}$

In the rest of this text Qandūsī sets the paintbrush aside and traces the words with a reed pen, on a smaller scale - about nine lines per page. (Figure 20.17). At first glance the completely original nature of the calligraphy (through the great plasticity of the formation of letters) might lead one to question its origins, and its links with local Maghribi traditions. However, careful observation allows one to uncover the calligrapher's attachment to the classical principles of the way of writing called maghribi al-mabsüț. The ordinary writing on these pages takes its form from the handwriting that was often used in medieval Maghribi Qurāns, as evidenced, for example, by the atrophied tails of certain letters, the particular punctuation of the letters $f \bar{a}$ ' and $q \bar{a} f$, the large opening in the nün and that of the 'ayn/ghayn. ${ }^{76}$ Qandūsī even refers to an ancient form

72 Of the twelve $a j z \bar{a}$, only volumes 3 to 12 are still preserved at the library; the first two volumes were offered as a gift by the Royal Library.

73 Waley, "L'ornementation du livre", 255.

74 Déroche, "Les emplois du Coran" 6o; Id. "Cercles et entrelacs" 6o6-7.

75 Déroche, "Le Prince et la Nourrice" 18-33.

76 Khemir, "The Art of the Book", 116. 


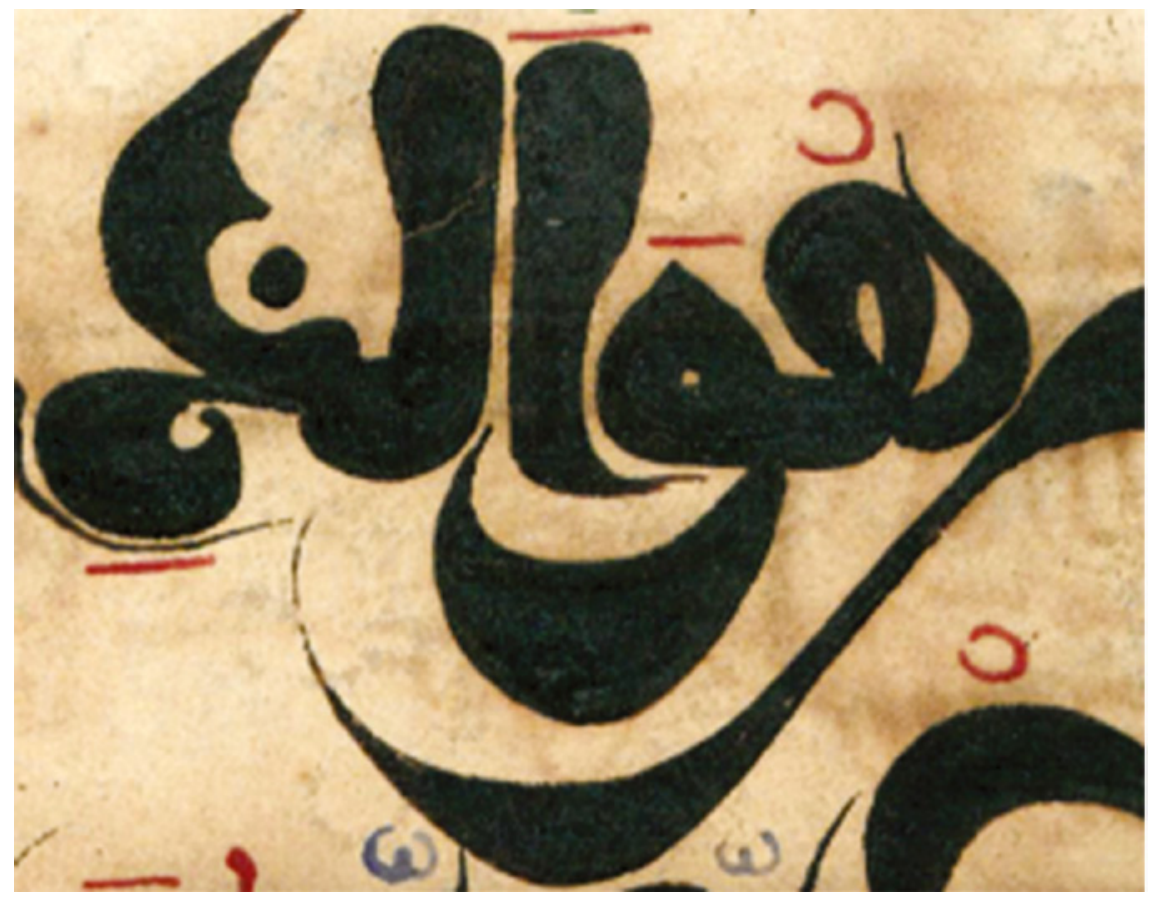

FIGURE 20.4 Detail of the outlining of letters in Qur'ān 12613, from vol. 12, f. 12a

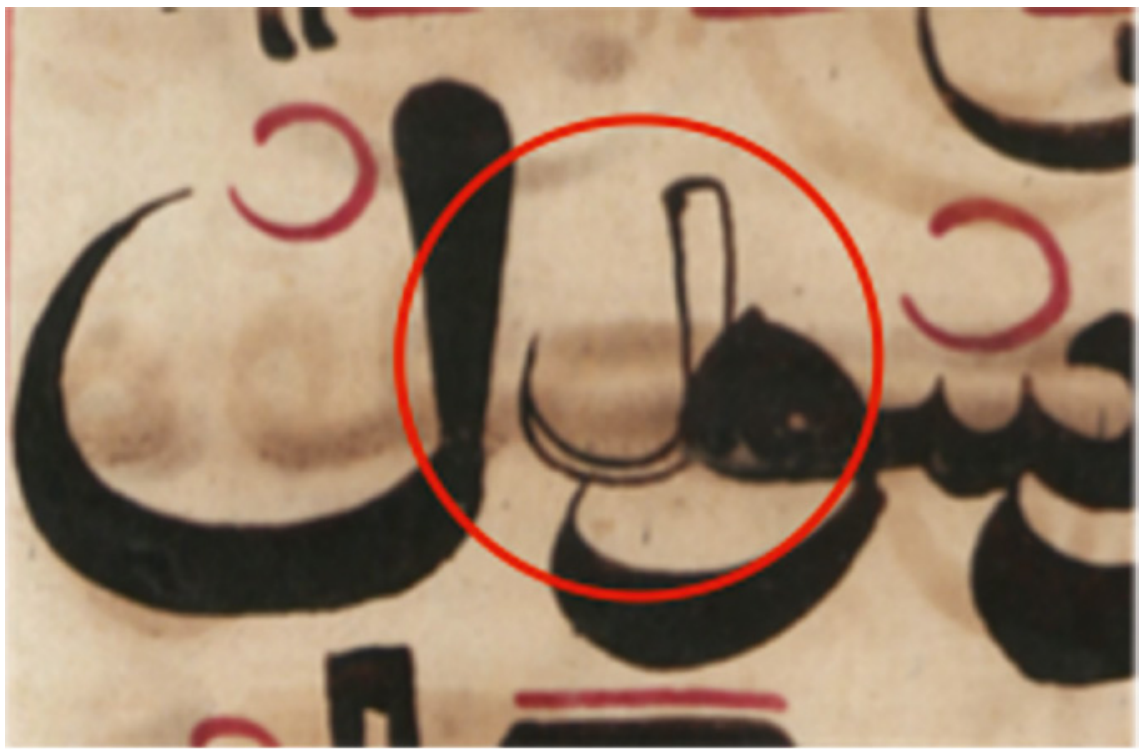

FIGURE 20.5 Detail of the outlining of letters in Qur'ān 12613, vol. 11, f. 36a 
of maghribi to draw the hamza, marking the hamzat al-wașl with a large orange (or, less frequently, yellow) dot and the hamzat al-qat ' with a green dot. It is clear that we can assume that the herb-seller benefited from a solid apprenticeship in Maghribi calligraphy, and that he takes care, in this official commission, to perpetuate its codes while adopting his own personal style.

Apart from a parsimonious use of gold and coloured inks in the titles, vocalisation marks and diacritical marks, Qandūsīs work is resolutely sober in appearance, in contrast to the great finesse of its execution (Figure 20.17). In addition, it may appear surprising that the separators between the verses are absent throughout all twelve volumes. We are tempted to ascribe this intentional restraint on the part of the calligrapher to the above-cited observations that he formulated in the $T a$ 'siss, on the importance of avoiding all distraction of the spirit that might be caused by the zakhrafa (illumination) and the colours in manuscripts, and of avoiding all excessive use of these techniques.

Essentially, it is through his tracing of the name Muhammad that he enhances these pages and gives free play to his art. In the Muhammad, al-Fath and $a l-A h z \bar{a} b$ Suras, he brings out the Prophet's name by amplifying the size of its letters and painting it using a technique similar to that employed for the first double page of each volume (Figures 20.6 and 20.8). For another occurrence he uses a no less original approach, tracing the contours of the name Muhammad in bright red ink and painting it in with black, thus giving it volume and making it stand out (Figure 20.7).

All of these practices contribute to enchanting the eye when it sees the Prophet's name, and to making its letters stand out from the rest of the text. What's more, the structure of the consonantal skeleton ( $\mathrm{rasm}$ ) of the name itself is surprising, to say the least. The initial mim floats above the letter $h \bar{a}$.

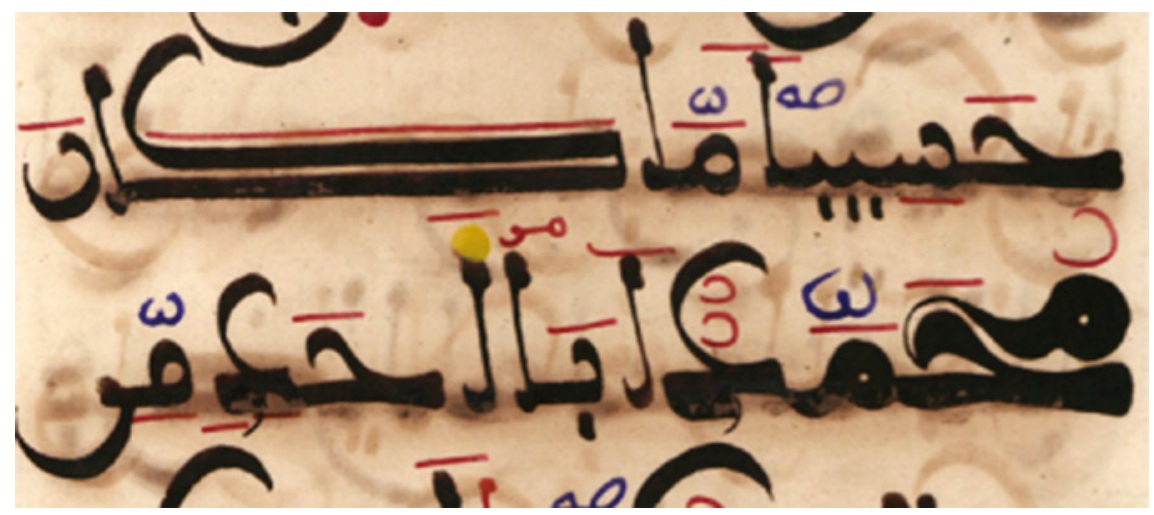

FIGURE 20.6 Writing "Muḥammad" - vol. 9, f. 46b 


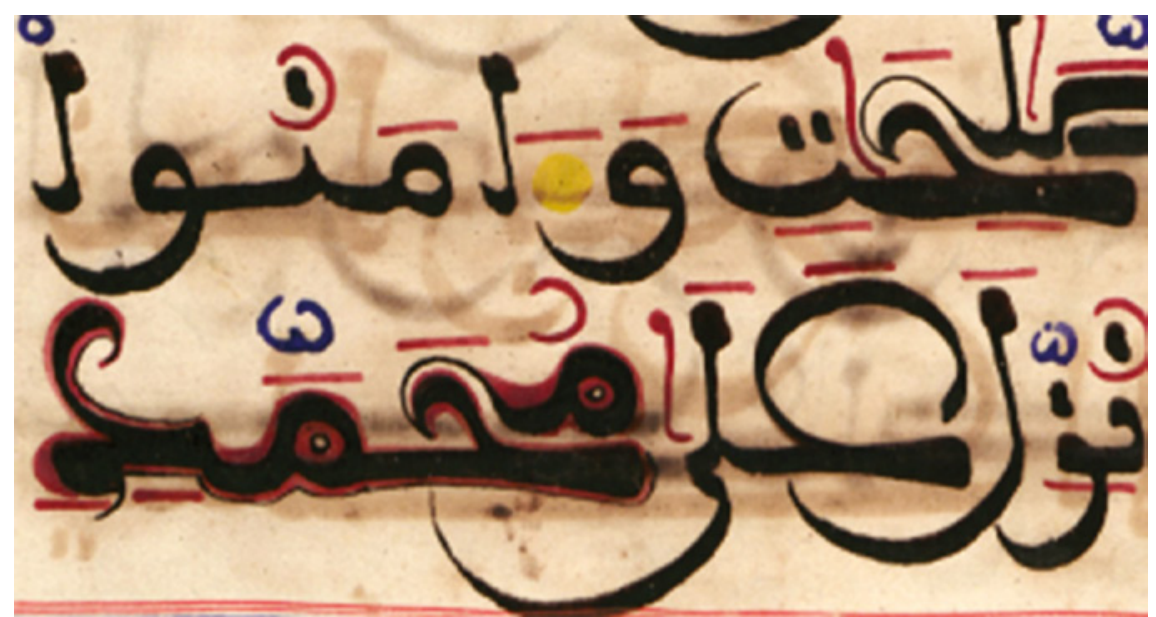

FIGURE 20.7 Writing "Muḥammad", vol. 11, f. 14a

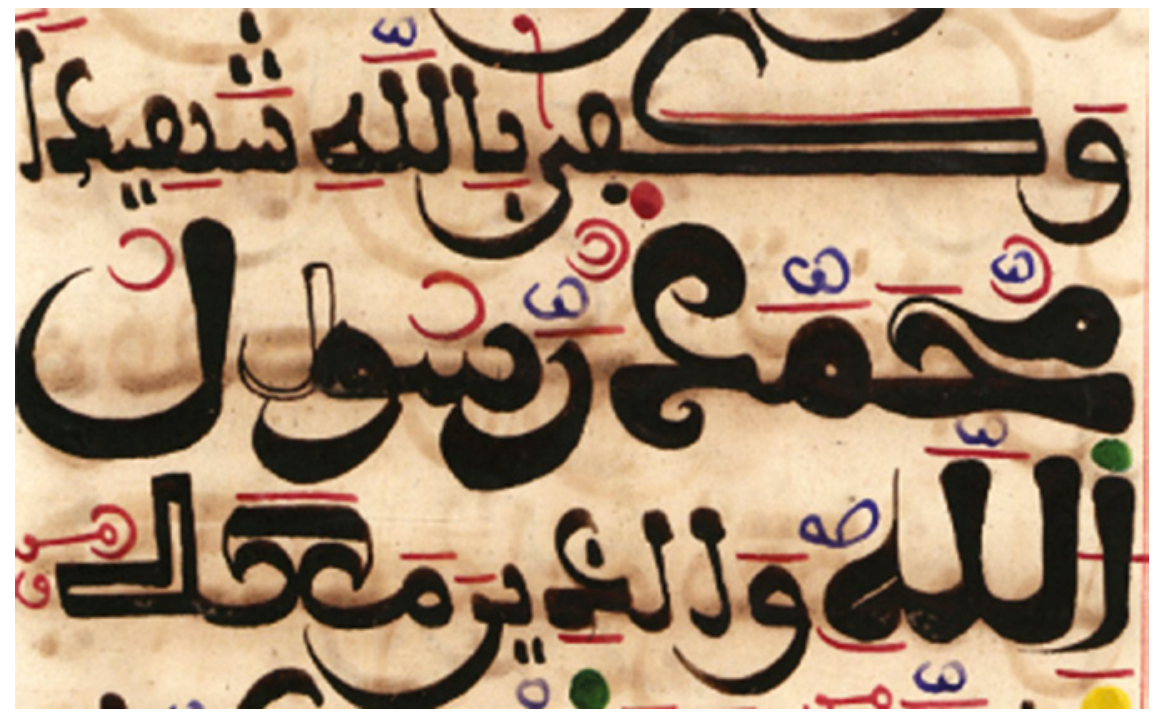

FIGURE 20.8 Writing "Muhammad" - vol. 11, f. 36a

This latter is designated by two curls that mirror each other, creating an additional echo in the negative space between the black lines. The great plasticity of the letters, especially the mim above the $h \bar{a}$, and the 'ayn in a median position, almost suggests recognisable forms or images. In the colophon of this Qưrān, Qandūsī devotes a few lines to the hidden powers of letters, and some of these passages recall the idea of the anthropomorphism of writing that he developed in his treatise, al-Ta'siss. Indeed, in f. 138a, he compares the letters of 


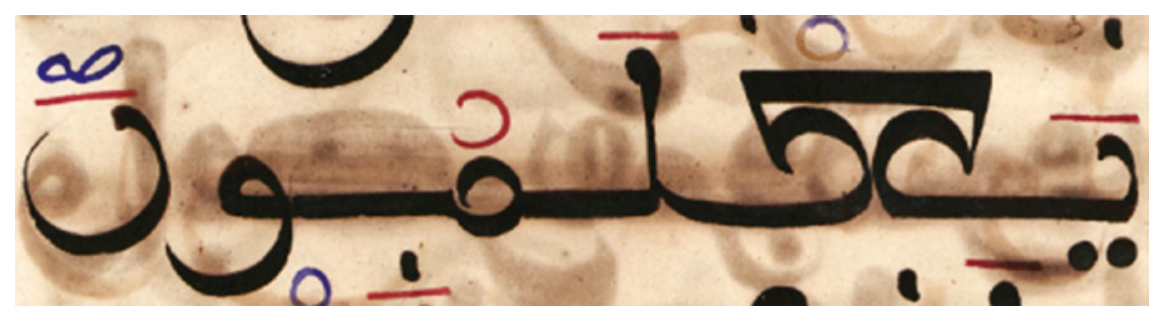

FIGURE 20.9 Qur’ān 12613, vol. 9, f. 116a

the Qurān to a fountain (al-khașșa) from which gushes (al-dāfiqa) the power of their hidden meanings (sirr al-hurüf), like a spring ('ayn) from which everyone can drink. Thus, one should drink from each letter as much as one wants (ighraf minhu mā shi'ta) in order to achieve healing from all diseases and from anything else (wa-stashfi bihi min amrādika wa-min kulli mā shita). ${ }^{77}$

If we examine the shapes of letters carefully, bearing this in mind, certain comments can be made (Figure 20.11): The grapheme $\mathcal{\varepsilon}$ ('ayn) in the median position in a word is formed of the meeting of two definitely concave, and symmetrical, marks, topped by a strong thick convex (or, in certain contexts, completely straight) line.

At each appearance of the letter 'ayn the two strokes that form it are extended so that they skim the base-line, making the letter look like a stylised fountain, as described in the colophon, where he compares the shapes of letters to that of a spring, "ayn" in Arabic (Figure 20.20). This sort of treatment of writing is rare in the Muslim west, unlike in the Mashriq, especially in Iran, where calligraphers conceived pictorial writing; there the border between writing and painting is very permeable. ${ }^{78}$ As early as the tenth/sixteenth century, zoomorphic calligraphy, formed by a word or phrase (often a pious formula) that was stretched and deformed so as to depict an animal figure, was very popular in Iran. Another technique, micrography, also consisted of the formation of an image from a written text, using a microscopic handwriting called ghubārī. ${ }^{79}$

77 Li-kawnihi al-ghinā' yansha'u min tajwīf hurüfihi kamā hum maftūhīna fa kull-ḥarf yanba'u min-hu 'aynan [sic] ka-l-khașșa al-däfiqa yashrabu minhā kullu man yariduhā

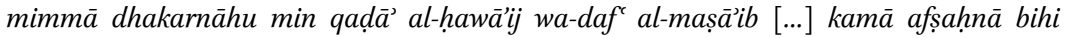
wa-khtașarnāhu tarā sirr al-ḥurūf wa-'adhb mā̇ihim [māyihim] al-mutadāfiq min kulli ḥarf ighraf minhu mā shi'ta wa-stashfi bihi min amrā ḍika wa-min kull mā shi'ta wa-aqḍi bihi mā shita.

78 Blair, "Pictorial writing".

79 Although this tiny writing is mostly encountered in manuscripts produced in Turkey during the tenth/sixteenth century (Vernay-Nouri, "Marges, gloses et décor"), the technique is very occasionally adopted in a few copies made in the Maghrib. In those instances, it is 
Although our calligrapher's graphic experiments were more restrained than those eastern creations, his observations on the anthropomorphism of letters, as expressed in his Ta'sis and reiterated in the colophon of this Qur'ān, remain no less original in the Maghribi calligraphic tradition.

This Qur'ān displays many aesthetic qualities, but in addition, our copyist uses the final two pages of the twelfth volume to tell readers of its talismanic functions. In the colophon he specifies that these twelve volumes are laden with blessings (baraka) for whoever carries them, turns their pages, or reads them. It will ensure the healing of all sickness, preserve from "all troubles", protect from demons (al-shayāținn), permit victory in battle (hamalahu li-l-harb wa-nawa bihi 'azimat al-juyūsh), and even ward off the danger of drowning at sea (hamalahu fi safina li-l-najät min al-gharāq fi-l-bahrr). We can assume that the realisation of a copy of the Quran that is explicitly endowed with such thaumaturgical and protective properties is the result of a clearly expressed desire on the part of the person commissioning the work and we know of the diplomatic activities and extensive (and sometimes dangerous) European journeys undertaken by Idrīs b. Muḥammad Idrīs al-'Amrāwī al-Zammūrīal-Idrīsīi ${ }^{80}$

\section{$4 \quad$ Forming the Letter, an Act of Prophetic Devotion}

The second manuscript we examine in this study, the copy of al-Jazūlì's Daläil al-Khayrāt $[399 \mathrm{~K}$ in the National Library of the Kingdom of Morocco] also contains talismanic elements. Kitāb Dalāill al-Khayrāt wa Shawāriq al-anwār fì dhikr al-șalāt 'alā al-Nabì al-mukhțār (The signs of benefits and resplendent lights in the enunciation of the prayer in honour of the chosen Prophet) is a collection of prayers and invocations of the Prophet that was put together towards the middle of the ninth/fifteenth century by the Moroccan mystic Muhammad

applied to marginal notes, written in a tiny hand and organised in such a way as to form the shapes of recognisable or ornamental objects. See the collection of texts called Kitāb sihr al-balāgha wa-sirr al-barā'a, by 'Abd al-Malik b. Muḥammad al-Tha'ālibī, probably written in Algeria in 1051 H/1643. Guesdon and Nouri, L'Art du livre arabe, 67.

8o Although the use of the Qurān as a talisman was strongly condemned by some jurists, the most famous of whom was Ibn Taymiyya (d. $728 / 1328$ ), the practice became common very early throughout the Muslim world. This may have been (in part) inspired by the last two Suras of the Book (Q 113 and 114), as in the following verses: "I take refuge with the Lord of the Daybreak from the evil of what He has created, from the evil of darkness when it gathers, from the evil of the women who blow on knots, from the evil of an envier when he envies." (Q 113:1-5, trans. Arberry). In such cases the use of the Qurān as a talisman rests on the recitation of this text, or the writing of it. For more on this, see "Lusage talismanique du Coran" 83-95; Id. ed., Coran et talismans. (change the font). 
b. Sulaymān al-Jazūlī (d. 869/1465). Unusually, the book contains illustrations representing the funerary chamber of the Prophet in the Medina mosque, and it rapidly became one of the most popular devotional books in the entire Sunnī Muslim world; reading it was considered to bring numerous blessings, as was the act of copying it. ${ }^{81}$

Qandūsī himself seems to have devoted much time and affection to copying this breviary, if we are to believe the tally established by specialists in Moroccan books, of seven copies by Qandūsī. Some of these were made for the royal family, or for important dignitaries in the Kingdom. We can assume that manuscript copy 634J in the National Library of the Kingdom of Morocco, finished in 1267/1850, was created for an important commissioner; it employs expensive materials and completely original and complex techniques or writing; it also features an abundance of illuminated decoration, certainly by an artist other than Qandūsī (Figure 20.20). As well as wanting to create beautiful copies of the Daläil al-Khayrät, our calligrapher also demonstrates a real care for the authentic transmission of this manual of tașliya on the Prophet, and seems to have a remarkable mastery of its text (Figure 20.21). In his copy $399 \mathrm{~K}$ (Figure 20.22), he inserts numerous marginal annotations in order to provide the reader with precise information about the hadiths on which the prayers in the book are based. ${ }^{82}$ Another sort of note refers to the autograph copy of the book of prayers (al-nuskha al-sahliyya), ${ }^{83}$ in order to attest to the authenticity and conformity of the text that he has re-read, corrected, and copied.

This preoccupation with conforming to the autograph copy demonstrates the extent of Qandūsì's familiarity with al-Jazūlì's text. This also seems to have been recognised by his contemporaries, who ask him to re-read copies of the breviary made by other hands, in order to verify that they are authentic. We have identified a note in Qandūsì's hand just after the explicit of another copy, certainly not made by him, of the collection of prayers, Daläil 5920, held in

81 For more on the manuscript tradition of the Daläil al-Khayrāt in the Muslim west, see Abid, "Les Dalāil al-Khayrāt".

82 For example, he attaches the first prayer, al-ṣalät al-ūla (f. 5oa), to the Shifä' and to the Muwațta'; the second șalät (f. 51a), is attached to the Shifä', the Muwațta' and the Sahịh Muslim, or else to the fifth prayer (f. 52b), in the Shifä' by the Qāḍi 'Iyāḍ.

83 The copy called "al-sahliyya" is the manuscript that would have been copied in 862/1457-8 by Muhammad al-Ṣughayyir al-Sahlī (d. 917/1511-12), disciple and close companion of Shaykh al-Jazūlī, after this latter had spent several years composing and checking his text. Many manuscripts, especially in the Mashriq, contain marginal references to the nuskha al-sahlīy in order to attest to the authenticity of the text: Cornell, Realm of the Saint, 177. See also Chapter 3, "La copie autographe: al-Nuskha al-Sahliyya", in Abid, Les Dalāìl al-Khayrāt, I, 64-66. 


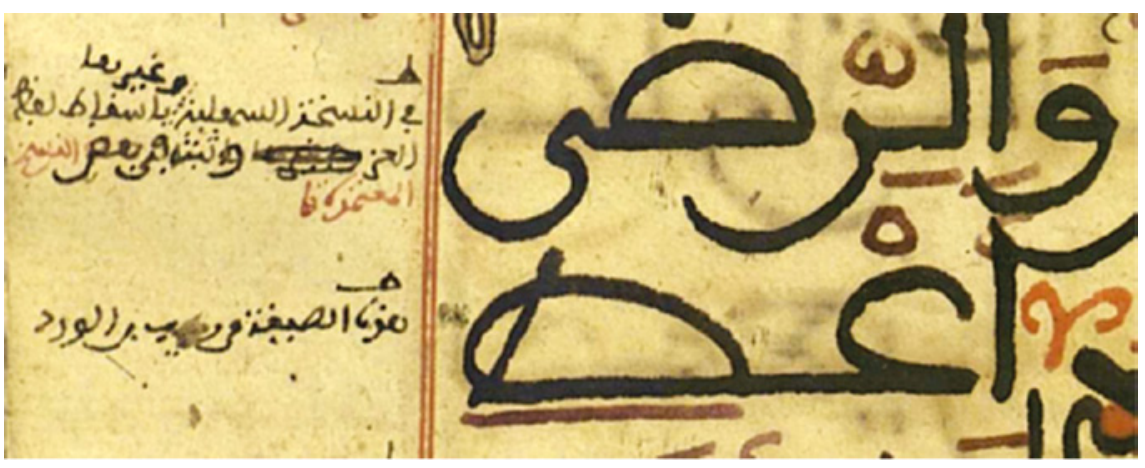

FIGURE 20.10 f. 69a: Marginal gloss about the autograph copy

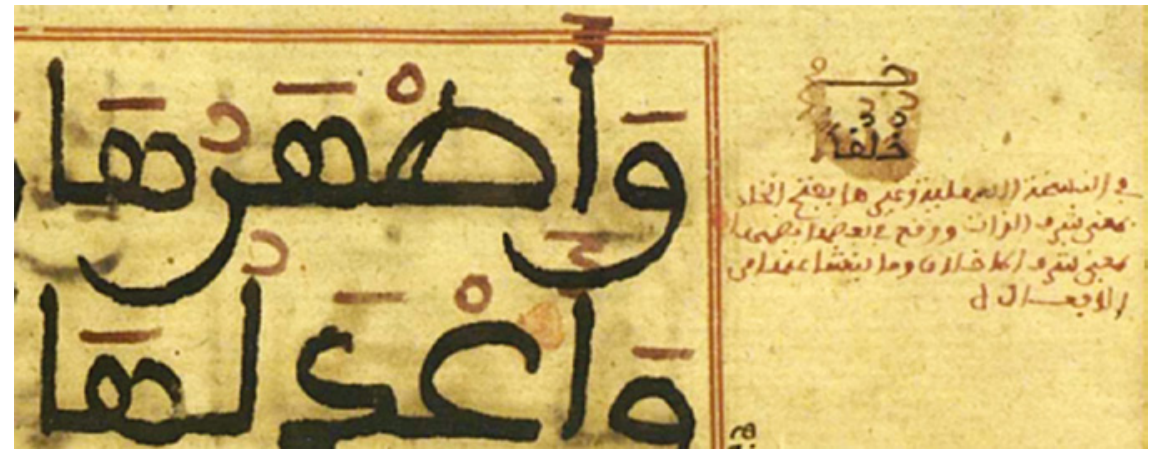

FIGURE 20.11 f. 87 b: Marginal glosses about the autograph copy

the Royal al-Hasaniyya Library and dated Dhü al-Qa'da 1200/August $1786 . .^{84}$ The calligrapher has added a few lines in which he attests to the conformity (tahqiq, tașdiq) of this copy to the autograph copy that is authoritative (tahqiq sanadihi), and assures the reader that he has completed an expert re-reading and careful correction of the copy. Amine Hamidoune, in his thesis, alerts us to the presence of two other Moroccan copies of the book of prayers that contain similar attestations from Qandūsī, the Dalā̉il 7959 in the Royal al-Ḥasaniyya Library, and J634 in the National Library of the Kingdom of Morocco, dated Friday 4 Muharram 1267/9 November 1850.85 Incontestably, our calligrapher was considered to be a legitimate muhaqqiq of the Daläil al-Khayrāt.

84 This manuscript was identified and analysed in Abid, Les Dalāil al-Khayrāt, I, 307 and II, 141-3.

85 We discovered this information too late to include these versions in the present chapter; we hope to consult and make use of them in future research. 


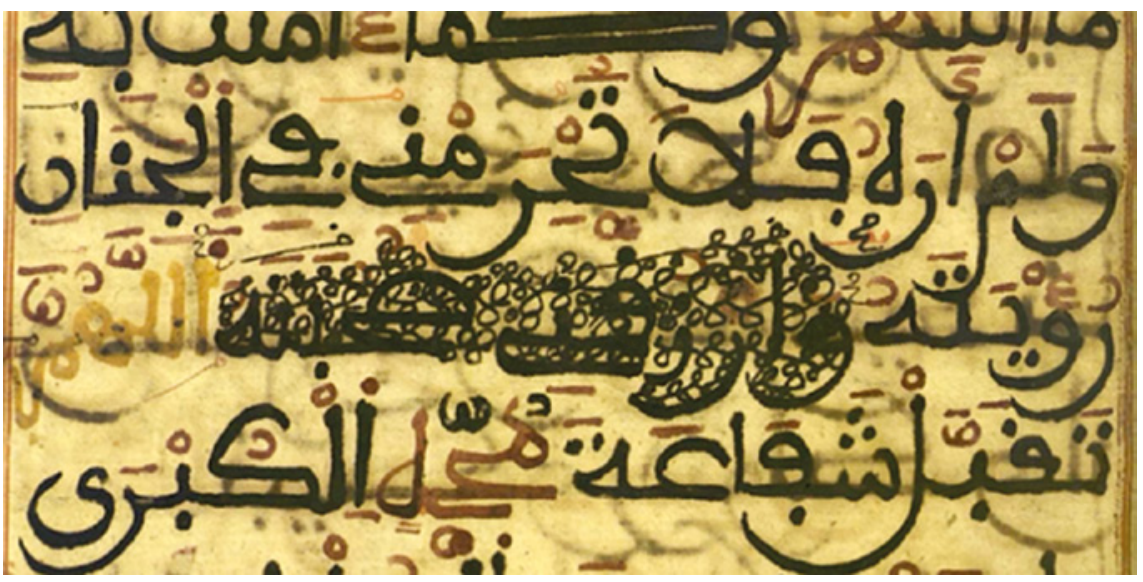

FIGURE 20.12 Examples of crossing out and clumsiness in the Dalāil al-Khayrāt 399K

Among all the copies of the Dalāil attributed to Qandūsī, manuscript $399 \mathrm{~K}$ from the National Library of the Kingdom of Morocco is the most singular, differing in several ways from most of his other artistic production. Unlike in the works we have evoked above, here the calligrapher undeniably frees himself from the habitual modalities of copying and illustration for a book of prayers, and also from the classical norms of Maghribi writing. This can probably be explained by the fact that Qandūsī made this copy for himself, as he says in the colophon: katabahu li-nafsihi (f. 154a); this formula was used in Arabic manuscripts copied by someone for his own use. ${ }^{86}$ This allows us to understand the presence of a plethora of marginal inscriptions throughout the book, along with the evident clumsiness of his writing of the main text. The calligrapher's line is often irregular, and the shape and lengths of the joins between the letters of individual words are not harmonised. On some pages he squeezes the words together, when the space remaining to finish a line is too small (al-tabyin, f. $174 \mathrm{~b}$ ), and in several other places he has crossed out segments (Figure 20.12). All this leads one to conclude that Qandūsì made this copy quickly, without an initial assessment of the page layouts.

This copy opens with several pages covered with prayers, alongside accounts of events in the religious life of Fez, or of the calligrapher's mystical experiences. Following this we find a series of pages covered with illuminations and writings, the sometimes uneven treatment of which, as in the rest of the book, indicates that they were very probably executed by the calligrapher himself. The first double carpet-page centres on a rectangle between two horizontal bands, containing a title announcing the Prophet's genealogy (Figure 20.23). This is 
part of a cycle of complex illuminated calligraphic compositions. Qandūsì is almost certainly the author of the paintings evoking the figure of the Prophet, because their style corresponds so closely with that of the text and the illuminations. Pages $17 \mathrm{~b}$ and $18 \mathrm{a}$ contain a topographical view of the sanctuary in Mecca and an interior view of the mosque in Medina (Figure 20.24). The latter image is made from an intimate view-point, but the former allows the reader to see the monument in Mecca in its entirety, with the different elements of its architecture set around the Kaba, which is at the centre of the composition. These illustrations are followed by a representation of the Prophet's sandals (ff. 18b-19a), among the most popular relics in Islam, particularly venerated in the Maghrib and since the medieval period (Figures 20.26 and 20.27). ${ }^{87}$ Prophetic traditions describe the Prophet's sandals (nicāl) in detail, and have been recounted in qașāild that explain their benefits. ${ }^{88}$ Travellers from the Maghrib went to Damascus, where the sandal attested to have belonged to the Prophet was held, in order to make precise drawings of it. These drawings were considered to have thaumaturgical and healing properties similar to those of the object itself. ${ }^{89}$ As a result, images of the relic began to circulate, especially in North Africa and al-Andalus; such images were regularly included in works of devotion to the Prophet, such as the Daläil al-Khayrāt.

In our copy, two representations of the relic are placed vertically, on facing pages (18b-19a), framed by a wide yellow band with oblique segments in black. In the centre of each image is an oval cartouche surrounded by a red band in which is a monumental inscription in yellow thuluth:

Umarrighu fì l-mithāli bayạ̣̄̂a wajhī *fa-qad jáala al-Nabiyyu lahā qibāla wa-mā ḥubbu l-nicăli shaghafna qalbī *wa-lākin ḥubbu man labisa al-nicāla

I rub the whiteness of my face against the sandal, for the Prophet himself set it before him.

This not from love for the shoe, but for he who wore it.

This formula is frequently associated with the drawings of the sandals in copies of the Daläil al-Khayrät, and bears witness to the intense devotion to the Prophet that is expressed through the contemplation of his relic.

\footnotetext{
87 Meri, "Relics of Piety and Power", 106-112; Margoliouth, "The relics of the Prophet Mohammed", 20-27.

88 Al-Mizzī, Tuhfat al-ațräf bi-márifat al-ațräf, cited in Juynboll, Encyclopedia of Canonical Hadith, 321.

89 Al-Maqqaī Fatḥ al-Muta'āl, 289.
} 
After these images, Qandūsī inserts an imposing and surprising passage of writing in black ink that covers two successive double-page spreads, 19b-2oa (Figure 20.26) and 2ob-21a (Figure 20.27). He uses the same technique as in Qur'ān 12613 but amplifies it still further here: he traces the contours of the letters, their sinuous extremities, and the vocalisation (damma, fatha) and diacritical (shadda) marks with a fine reed pen, before blocking in the large surfaces in black with a paintbrush.

The first double page (Figure 20.26) features the basmala and the profession of faith, which extends from the right-hand side of the first page to the second page. For the first three letters of the basmala, the copyist stretches the vertical tail of the mim along the whole height of the page, so that it lies beside and to the left of the rest of the basmala, forming, with the final mim of "al-rahìm", two parallel lines. In contrast with this page's parallel vertical lines, formed by the stems of the letters ( $b i$ in bismillāh, the alîf lāms of al-rahmān and al-rahim), the left-hand page offers a denser, more "enveloping" composition, obtained by the pronounced and repeated curves in the letters läm and alîf, and the $r \bar{a}$ ' of $r a s \bar{u} l$, which rolls itself around the $\sin$ and the $w \bar{a} w$ and ends with a sinuous descending tail; finally, the lām embraces the name of "Allāh".

The following double page (Figure 27) is devoted to the names of Allāh and Muhammad, written in a thicker, more monumental mode than the preceding pages. This composition is strongly reminiscent of a calligraphed sign bearing the monumental inscription Allāh, created by Qandūsì for the mosque of Moulay Idrīs II in Fez (see Figure 20.1 above).${ }^{90}$ In manuscript 399K the divine name is deployed in a manner that is equally imposing, and takes up almost the entirety of the double page spread, while the name of Muhammad is tucked in under the final $h a$ of Alläh, thus accentuating (as Blair has pointed out) its semantic importance. ${ }^{91}$ Here, with the mim floating above the ha, the rasm of the name Muhammad is identical to what we have observed in Qandūsì's other productions, as if he had codified this way of writing the name. Here, however, the exceptionally monumental nature of the writing, and its great plasticity, particularly in the tracing of the Prophet's name, liken this more to a painting intended to be seen and contemplated than to words meant to be read. In this way the calligrapher transcends the acts of writing and reading, showing us something beyond just the word as a word. ${ }^{92}$ This is underlined in the blocks of very small writing, similar to a ghubärì (munammal), disseminated in the

90 The original panel executed by Qandūsī has been replaced by a recent reproduction, which hangs on one of the internal walls of the Moulay Idrīs II mosque.

91 Blair, Islamic Calligraphy, 569.

92 Gonzalez, "Interprétation phénoménologique", 162. 


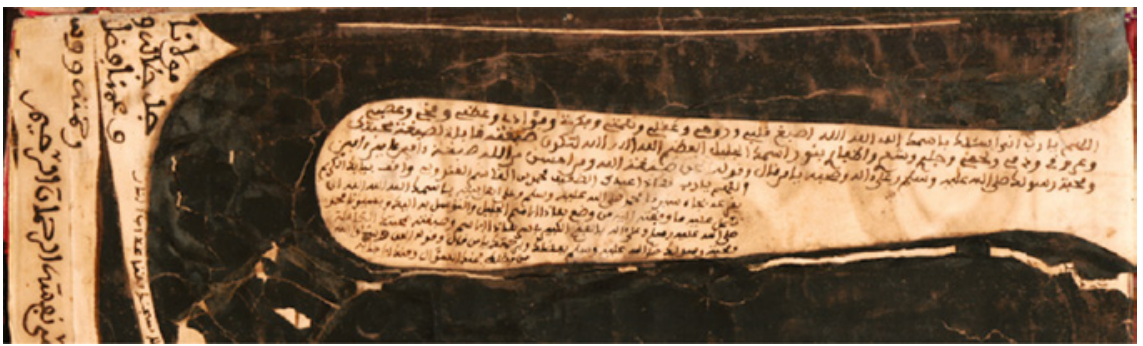

FIGURE 20.13 Qandūsī's prayer in microscopic writing between the stems of monumental letters, f. $20 \mathrm{~b}$

spaces left between the stems of the letters (alîf and lām) and under the final $h \bar{a}$ (Figure 20.13). In these we can read the following:

Allāhumma, O Lord, I ask you by Thy Name Allāh Allāh Allāh: hold my heart, my spirit, my intellect, my spiritual energy, my reflection, my conscience, my bones, my fingers, my brain, my veins, my blood, my flesh, my skin, my hair, and my nails by the light of Thy immense and majestic Name Allāh Allāh Allāh in order that its tint should correspond to the tint of the love that I bear Thee and to the love of Thy Envoy - peace and blessings be upon him, his family, and his companions, O All-Merciful One! Thy Word is truth! "We have taken on the colouration of God; and who better than God to offer such a tint"? ${ }^{93}$ (Q $\left.2: 138\right)$, Amin! [...].

This is a very elaborate prayer. It springs from the practice of calligraphy and draws on the main ritual formulas of Islam. But the calligrapher fills the voids between the letters with a request for a physical transmutation through which each detail of his body will take on the tint (șibgha) that God attributes to Himself in the Qur'ân. The passage would gain in clarity if we translated șibgha as "colour", but (speculatively) the implication may also be drawn, from the insistent use of black in these pages, that in this world the light of the Name of God can only be represented by its opposite, darkness. The Qurānic passage to which Qandūsī refers, verse 2:13 ${ }^{94}$ is, according to early commentators, part of an anti-Christian polemic: the șibgha is said to be an "unction" used to baptise newborns. God attributes the "best of unctions" to himself. The term also refers to a dye used to mark the foreheads of the faithful, and has previously been understood in an allegorical manner: Tabarī (d. 310/923), among others,

93 Author's own translation.

94 "Sibghat Allāh wa man aḥsanu min Allāh șibghatan wa naḥnu lahu àbidun." 
understands the term to signify the Abrahamic religion (haniffyya) or primordial nature (fitra). ${ }^{95}$ Sufi commentators see it as spiritual "mark"; for Qushayrī (d. 1074), "the sibgha of spirits and of the intimate secrets is the light of spiritual realisation" (anwār al-tahqüq). ${ }^{96}$ For Qandūsī, this metaphor becomes a physical process, transfiguring his being.

By choosing this term whose common meaning is "colouration", Qandūsī establishes an immediate link between the technique used to elaborate the name of Allāh and the Prophet on the one hand (black paint applied with a brush), and his ardent supplication, on the other.

Unlike the preceding examples, which were produced in response to a commission, the Daläil al-Khayrät $399 \mathrm{~K}$ was the result of an act of personal devotion on the part of the calligrapher. It bears all the signs of having been executed by Qandūsì with the aim of bringing himself closer to the figure of the Prophet, and gaining access to the divine presence. Its iconography multiplies indicators of the Prophet's presence such as his tomb, sandal, minbar, mihrāb, family tree, etc. Aesthetically, this manuscript announces itself through its concept of a calligraphic style that is unprecedented in the history of Maghribi writing and was elaborated specifically to express Qandūsìs piety. Writing down the Prophet's name, and that of Allāh, is indeed considered by copyists to be an act of piety that is full of benefits. Elsewhere, Prophetic traditions celebrate the benefits assured to the copyist who writes the basmala in a beautiful hand. 'Alī b. Abī Țālib records the Prophet as having used these words (which are widely read and commented on, notably by Ibn Khaldūn in his Muqaddima):97 "man kataba bismillāhi l-raḥmān al-raḥim bi-ḥusni al-khațti, dakhala al-jannata bi-ghayri hisāb" (Whosoever writes the basmala in a beautiful hand [husn al-khatt $]$ will enter Paradise without judgement). ${ }^{98}$ Here this means shaping the pious formulas, and the names of Muhammad and Allāh, with a tool, the paintbrush, that is exceptional in the Muslim West; for Qandūsī this unusual approach is justified by his hope of being soaked in the light of the Ism al-Jaläla in the same way as he soaks his paper with black paint.

Finally, the general impression of neglect of the rules for laying out a page, for writing or for the design of the decoration, of which we have spoken above, leads one to believe that Qandūsĩ was working in a hurry. Is it therefore possible that he made this copy in a state that could be called ecstatic, inspired by

\footnotetext{
95 Ṭabarī,Jāmi' al-bayān, III, 117-20.

96 Qushayrī, Lațāîf al-ishārāt, I, 112.

97 Rosenthal (tr.), Ibn Khaldûn, The Muqaddimah, 388-9.

98 Schick, "The Content of Form", 174.
} 
luminous visions? The malāmatī calligrapher provides accounts of visionary episodes of this sort in the pages preceding the text of the Daläil, in which he evokes, among other experiences, the moment the Prophet appeared to him and conversed with him, one day when he was sitting in his stall in the Fez herb market.

\section{$5 \quad$ Conclusion}

Muḥammad b. al-Qāsim b. Aḥmad al-Qandūsì's œuvre is a precious study resource for both Islamologists and historians of Islamic art. For the former it contains the prolific literary production by the malāmatì himself, most of which has not yet been printed or published; it has much to contribute to the study of Sufi doctrines and practices in thirteenth/nineteenth century Morocco. This œuvre also asks important questions about the circulation and mixing of knowledge, styles and ideas, making possible - indeed, necessitating - the breaking down of barriers between different approaches and methods. In the same way, the historian of Islamic art finds the opportunity to study the circumstances of the emergence of an aesthetic and way of writing that were completely novel in the history of art in the Maghrib, a cultural space that is generally held to be very conservative artistically. What's more, nowhere else in the Moroccan context is it possible to read the original work of the artist in the light of his own comments on calligraphic practice, which appear in filigree in his treatises, or in the margins and colophons of his manuscripts; this information is all the more valuable for being rare even in the eastern part of the Muslim world, where, despite the existence of treatises devoted to the production of inks or to bookbinding, theoretical texts on the art of calligraphy are few. This is in contrast with the situation in the Mashriq, where numerous such texts were produced from as early as the fifth/eleventh century; ${ }^{99}$ the genre flourished there during the eleventh/seventeenth century. This means that Qandūsì's remarks in his al-Ta'sis - few and tenuous though they are - on the subjects of the use of colours, or the ways of shaping letters, make an incalculable contribution to the history of cultural attitudes to the art of calligraphy in the Maghrib.

99 In his poem al-Qașīda al-Rā'tya, Ibn al-Bawwāb (d. 1022) writes as follows: "yā man yurīdu ijädata al-tahrīiri / wayarūmu ḥusna l-khaț̣i wa-l-tașwīri", O thou who aspirest to beautify thy writing/ and desirest the line of beauty [husn al-khatt $]$. 
An approach combining Islamology, codicology and the history of Islamic art has allowed us to bring out Qandūsì's doctrinal positions, which bridge the gap between a classical religious training, as revealed by his reading and his teachings, and, breaking through in his accounts of his ecstatic states or his encounters with the jinn Shamharūsh, a concept of Islam that is often less dogmatic. As we have seen, this synthesis in his thinking is also confirmed in his calligraphic art, in which, beyond the seeming rupture represented by his monumental and mannered graphic style, he is perpetuating the traditional graphic principles of the maghribī, and even reverting to archaic rules, particularly in his twelve-volume Qurān. 


\section{Additional Figures}

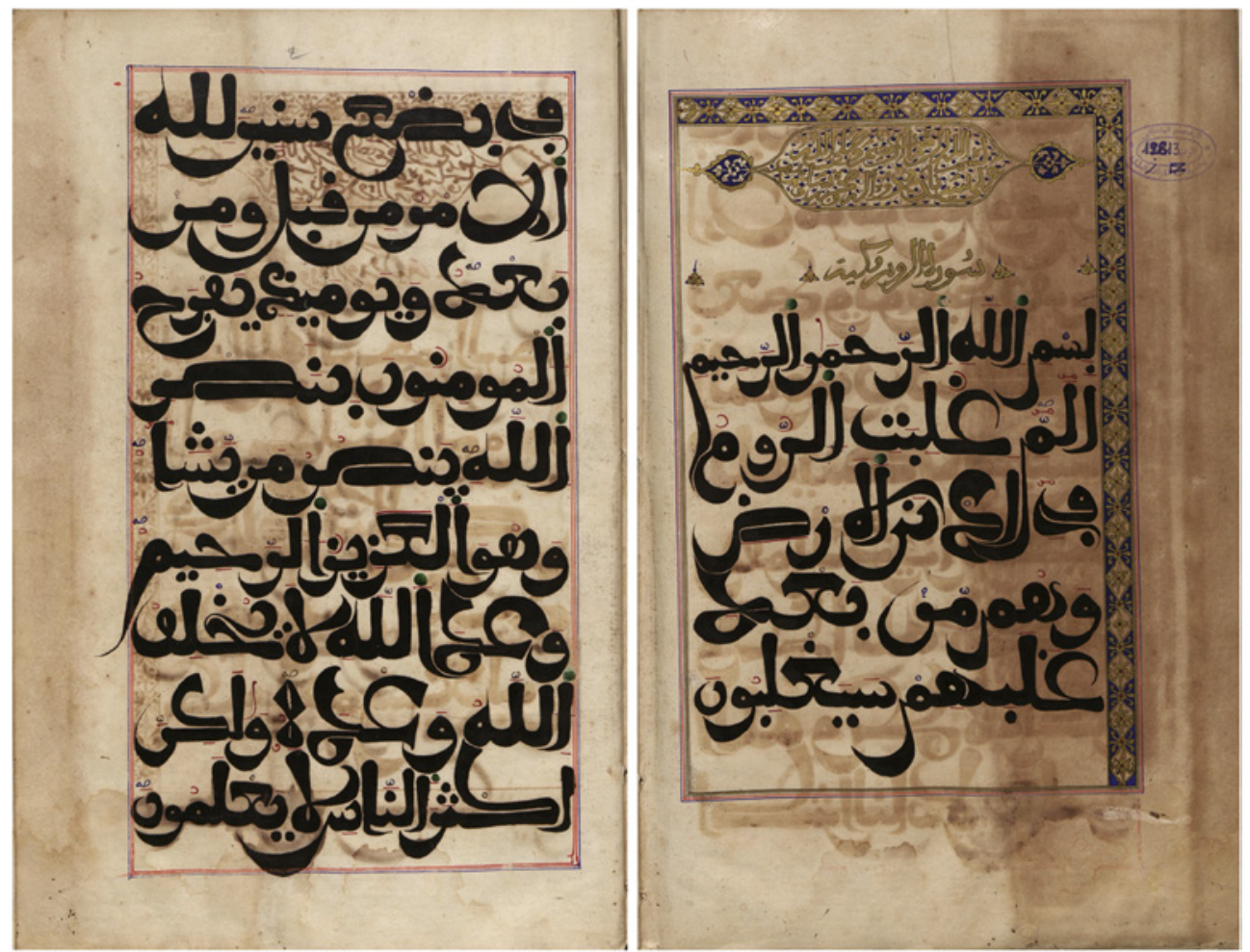

FIGURE 20.14 Illuminated opening pages of volume 9 of the Qurān 12613, Sūra 3o, ff. 1b-2a, al-Ḥasaniyya Royal Library 


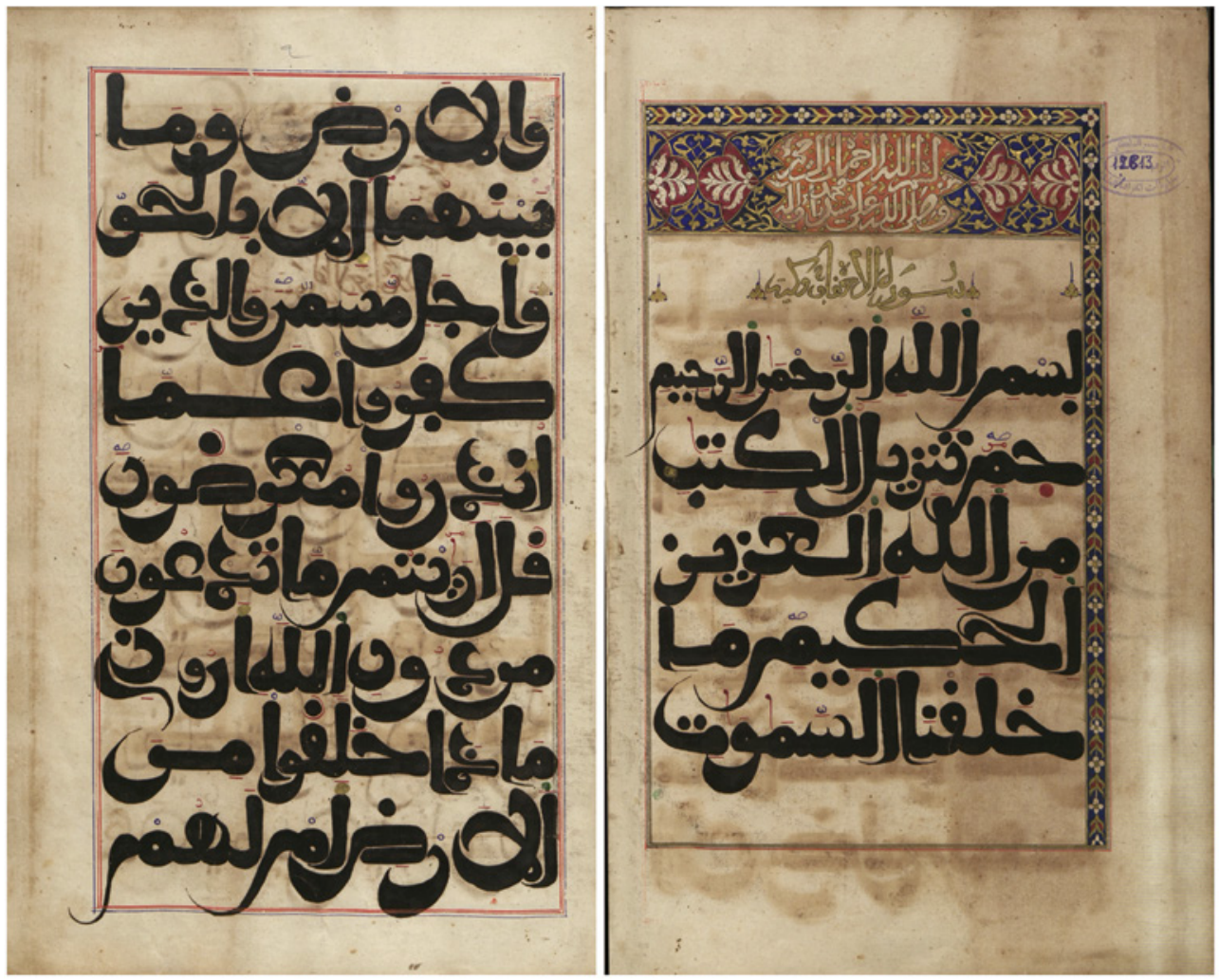

FIGURE 20.15 Illuminated opening pages of volume 11 of the Qur'ān 12613, Sūra 46, ff. 1b-2a, al-Ḥasaniyya Royal Library 


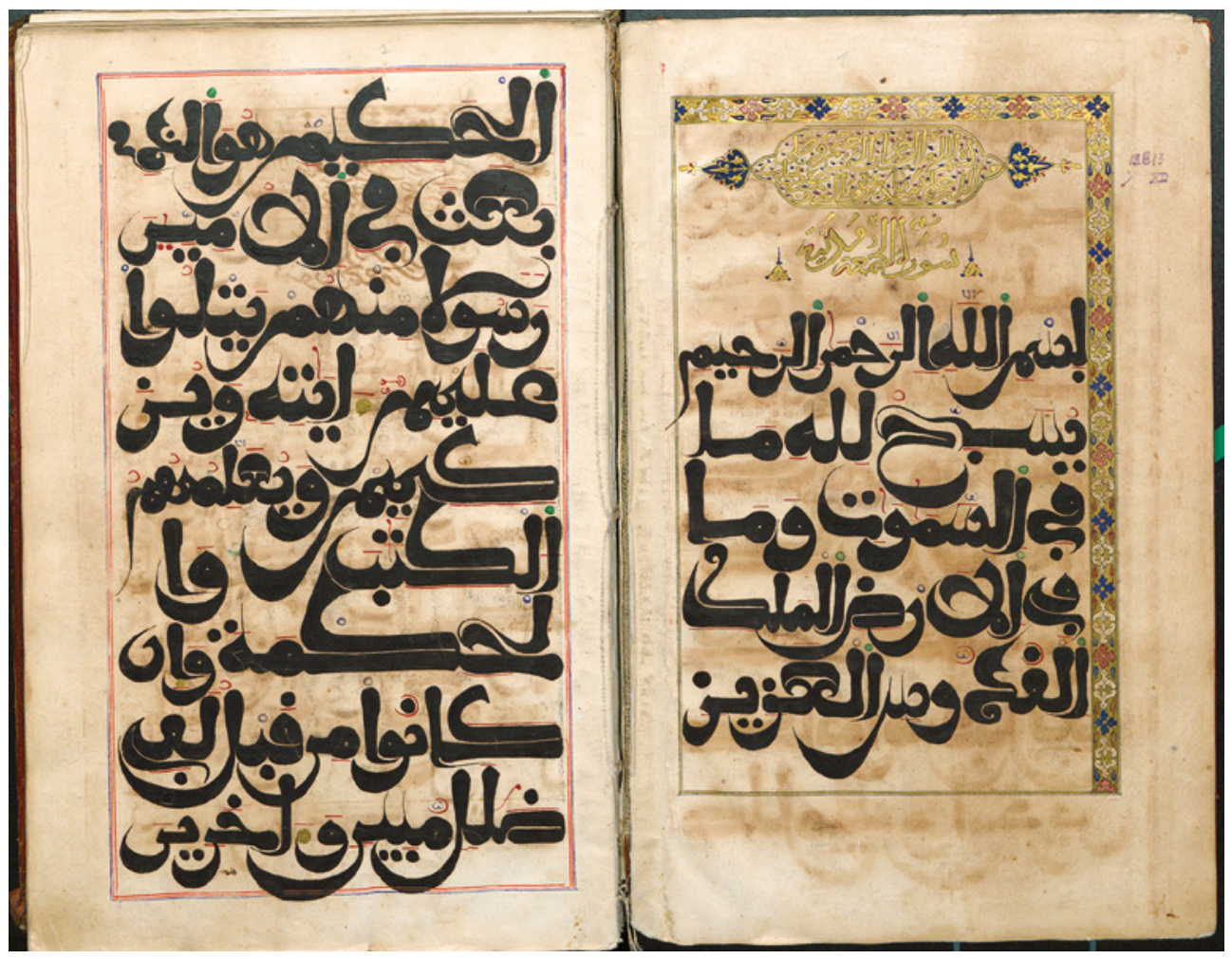

FIGURE 20.16 Illuminated opening pages of volume 12 of the Qurān 12613, Sūra 62, ff. 1b-2a, al-Ḥasaniyya Royal Library 


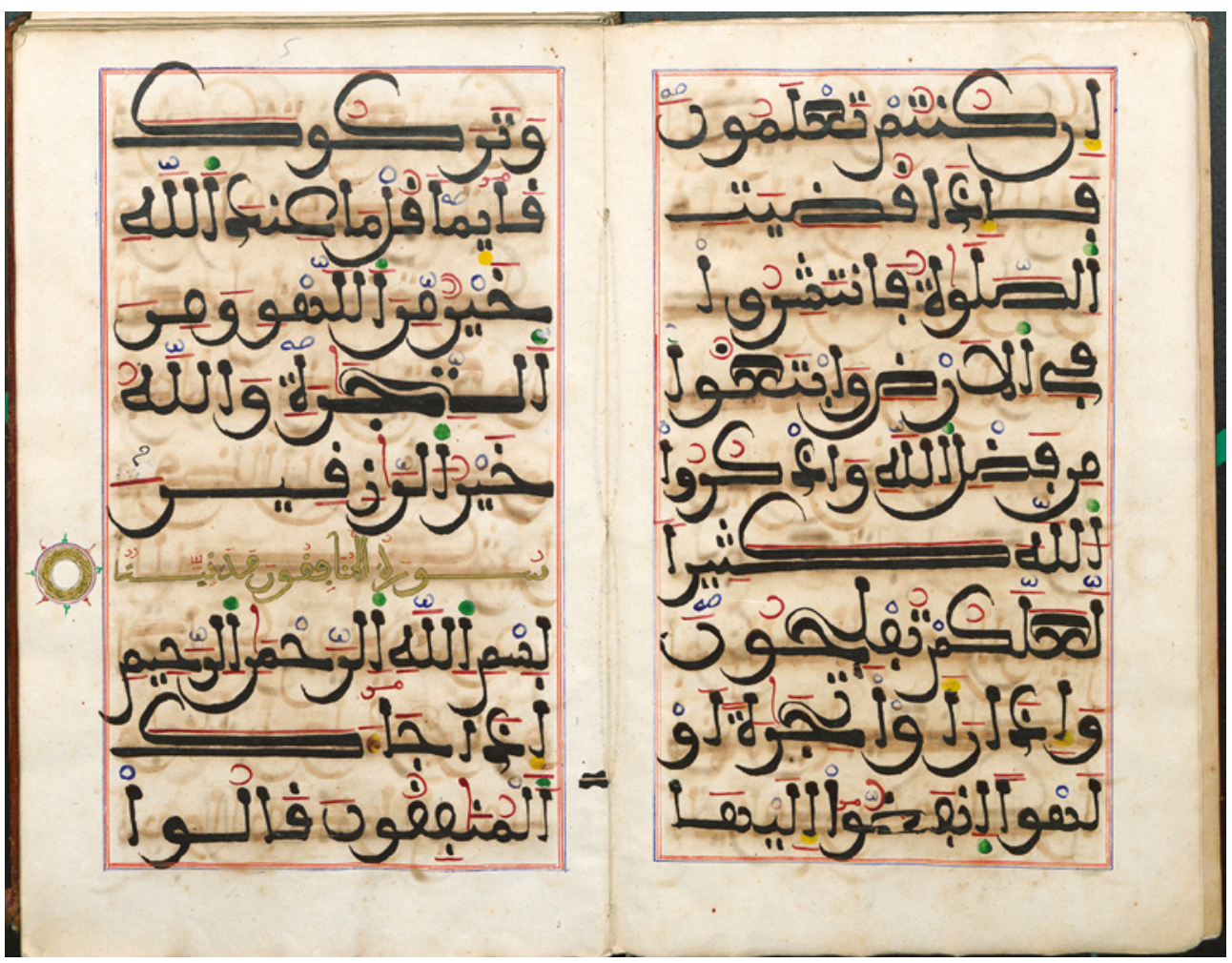

FIGURE 20.17 Double page of text of volume 12 of the Qurān_Sūra 62, 63, ff. 4b-5a, al-Ḥasaniyya Royal Library 


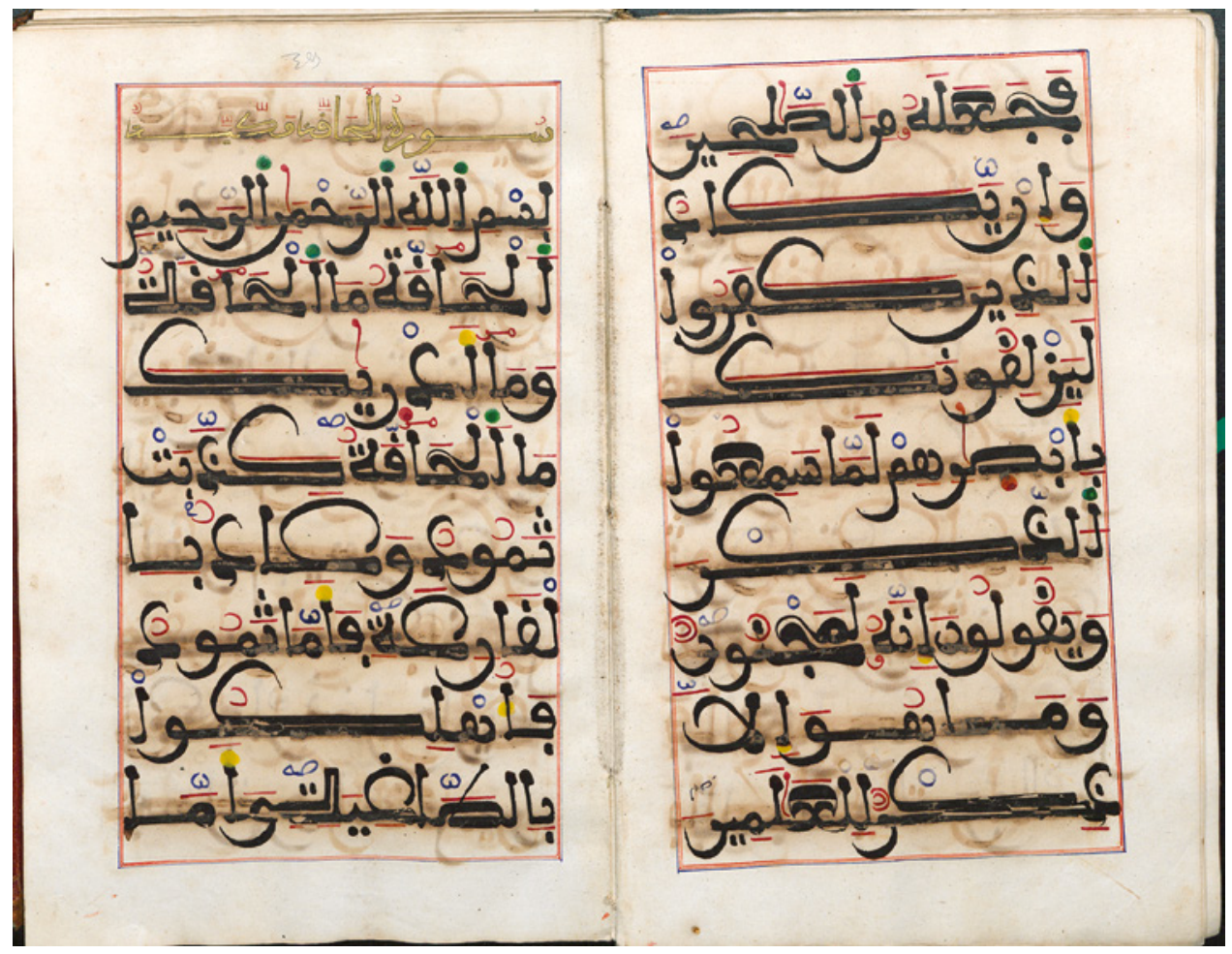

FIGURE 20.18 Double page of text with sūra golden title of volume 12 of the Qurān 12613, Sūra-s 68, 69, ff. 38-39a, al-Hasaniyya Royal Library 


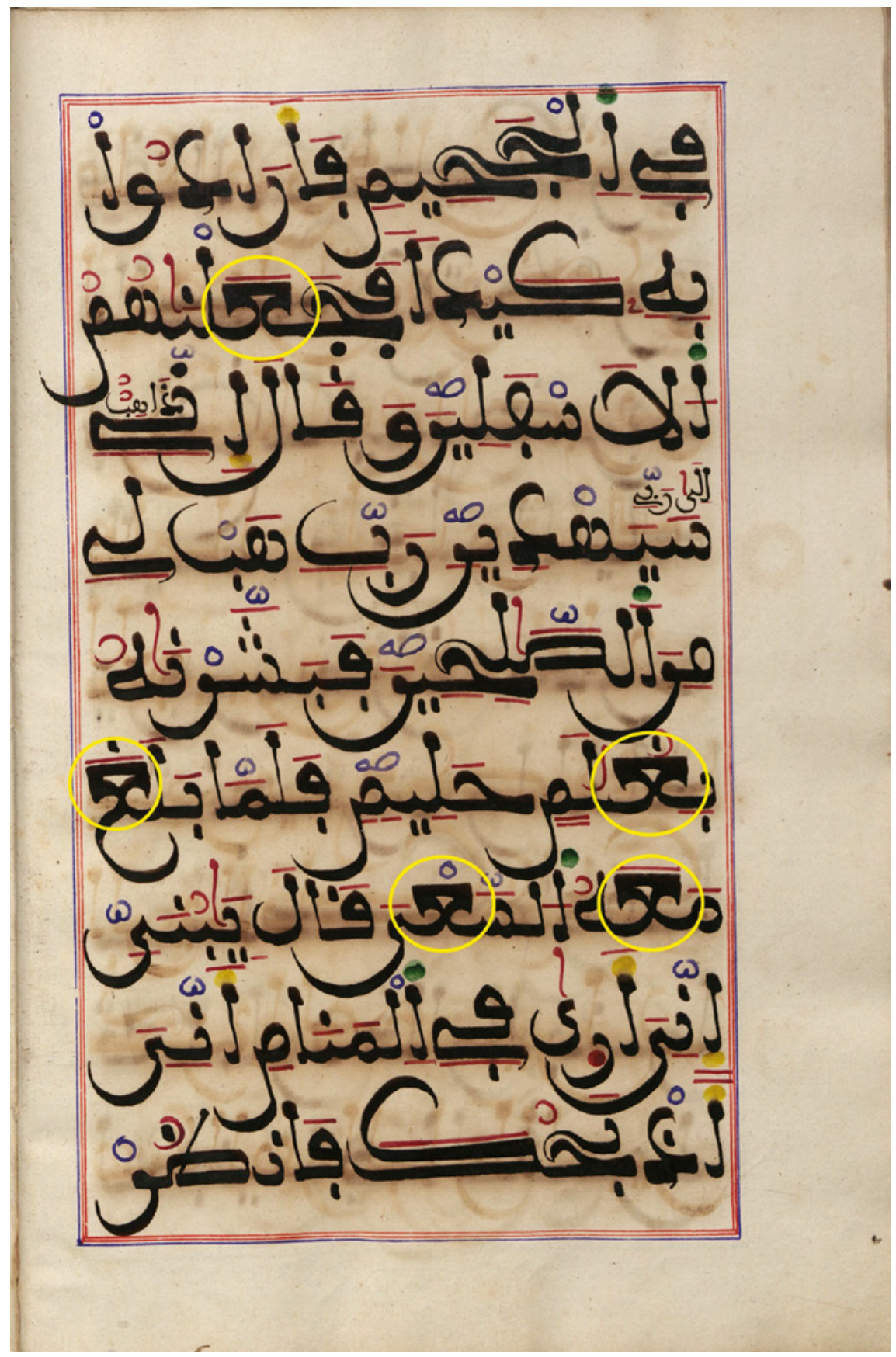

FIGURE 20.19 Writing of the 'ayn in volume 9 of the Qur'ān 12613, Sūra 37, al-Hasaniyya Royal Library_109b 


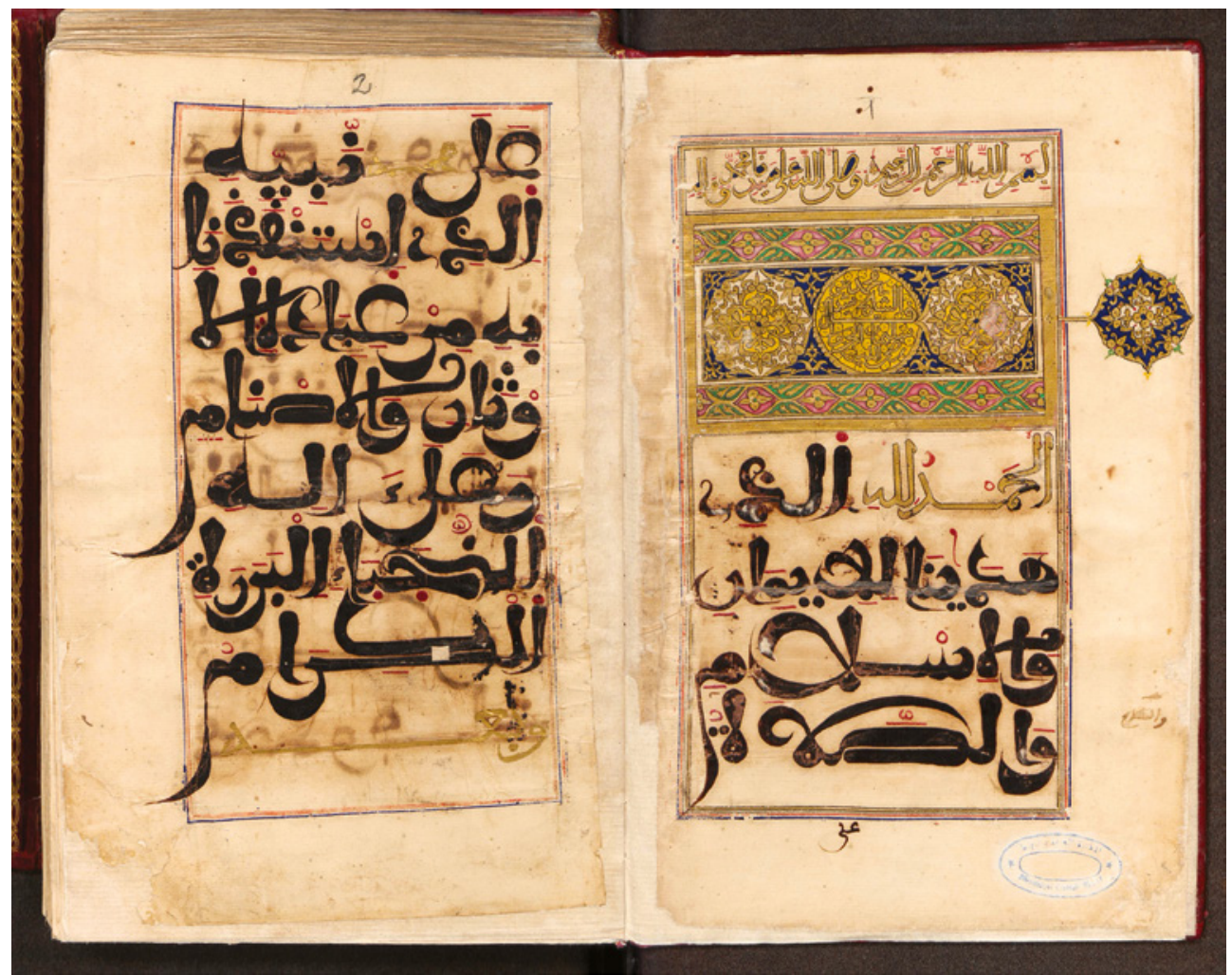

FIGURE 20.20 Illuminated double frontispiece of the Dalāil al-Khayrāt J634, National Library of the Kingdom of Morocco, ff. $1 \mathrm{~b}-2 \mathrm{a}$ 


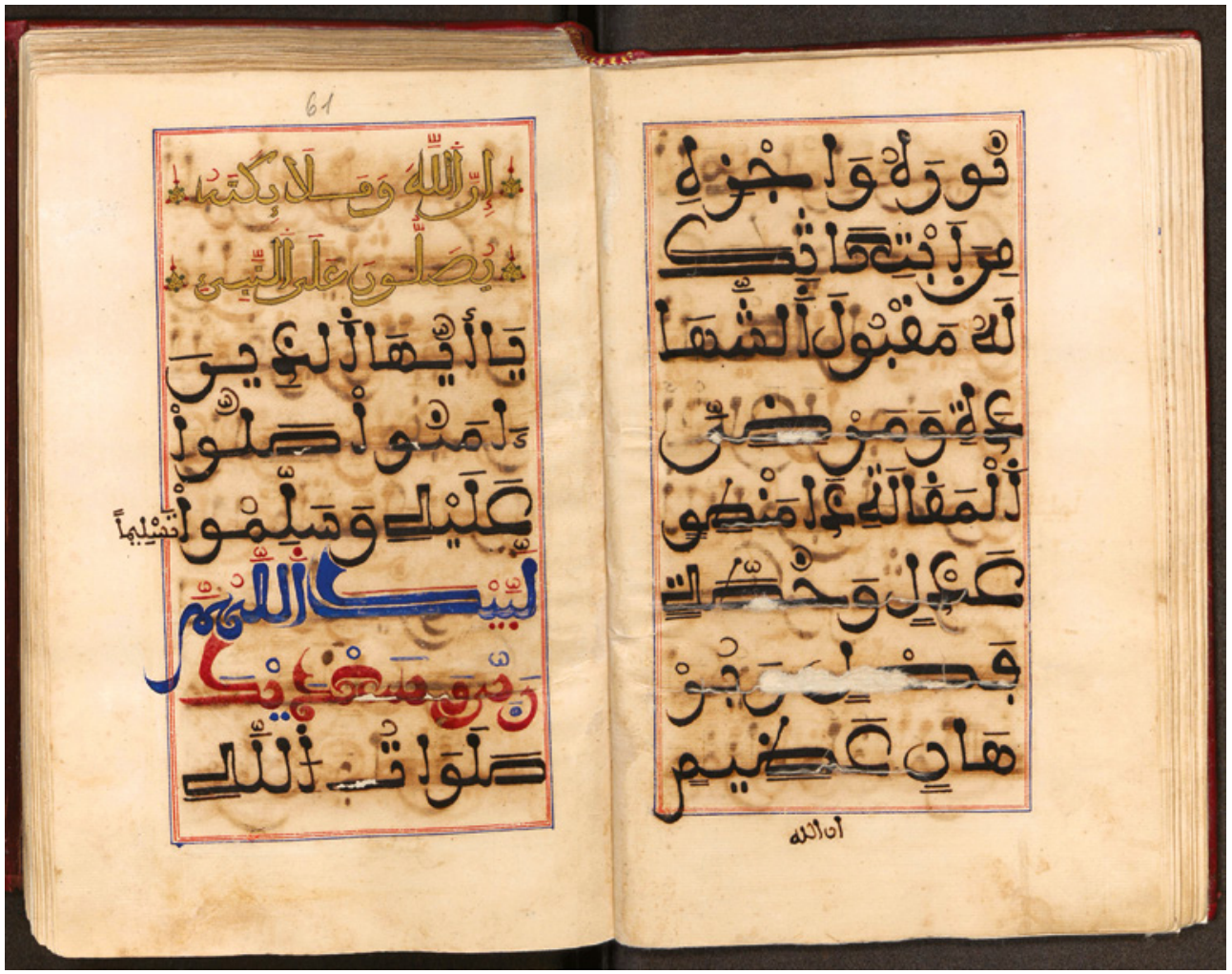

FIGURE 20.21 Double page of text with the use of gold and coloured inks and ornamental motives, Dalāil al-Khayrāt J634, ff. 59b-61a, National Library of the Kingdom of Morocco 

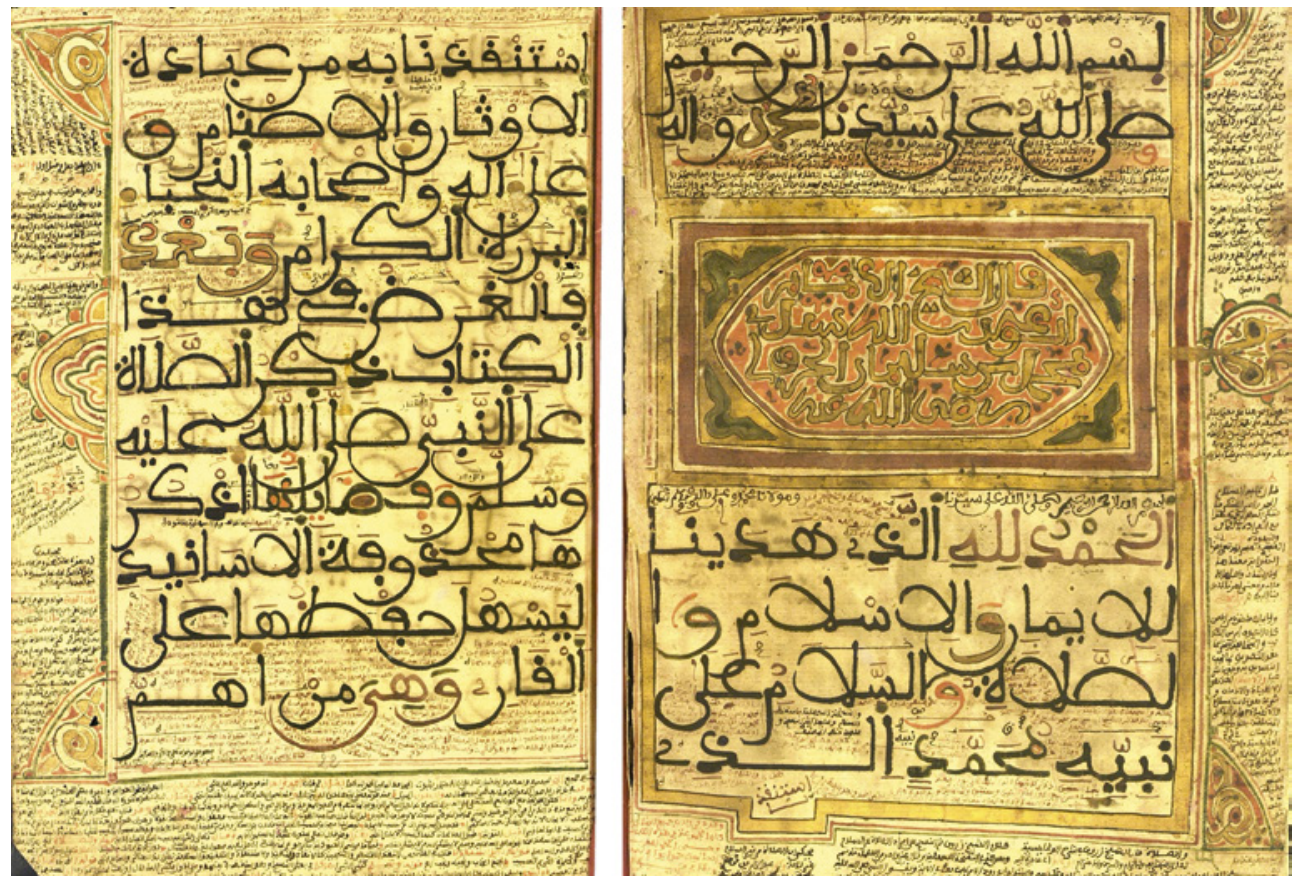

FIGURE 20.22 Illuminated opening pages of the text of the Dalāil al-Khayrāt K399, National Library of the Kingdom of Morocco, ff. $2 \mathrm{ob}-21 \mathrm{a}$ 

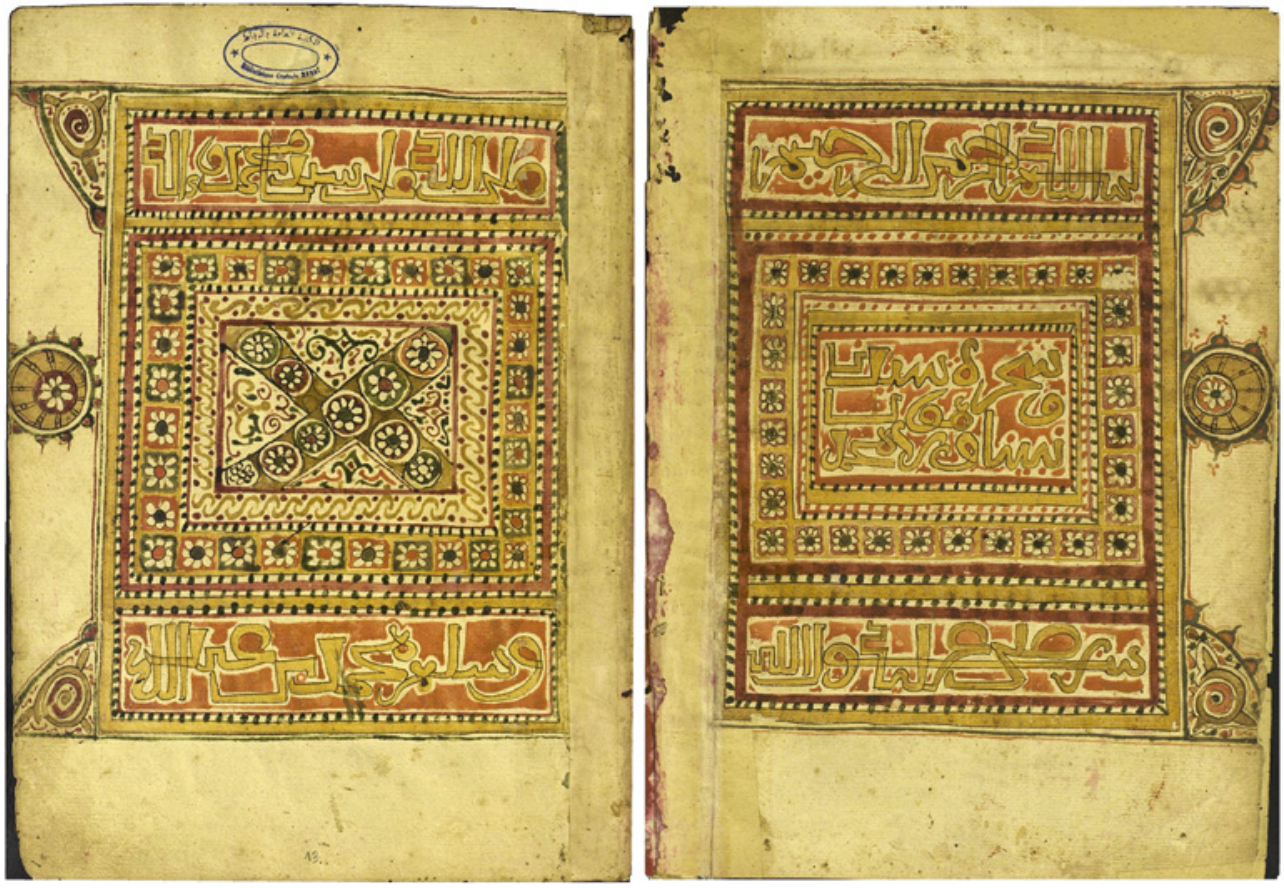

FIGURE 20.23 Double frontispiece of the Dalāil al-Khayrāt 399K, f. 12b-13a, National Library of the Kingdom of Morocco 

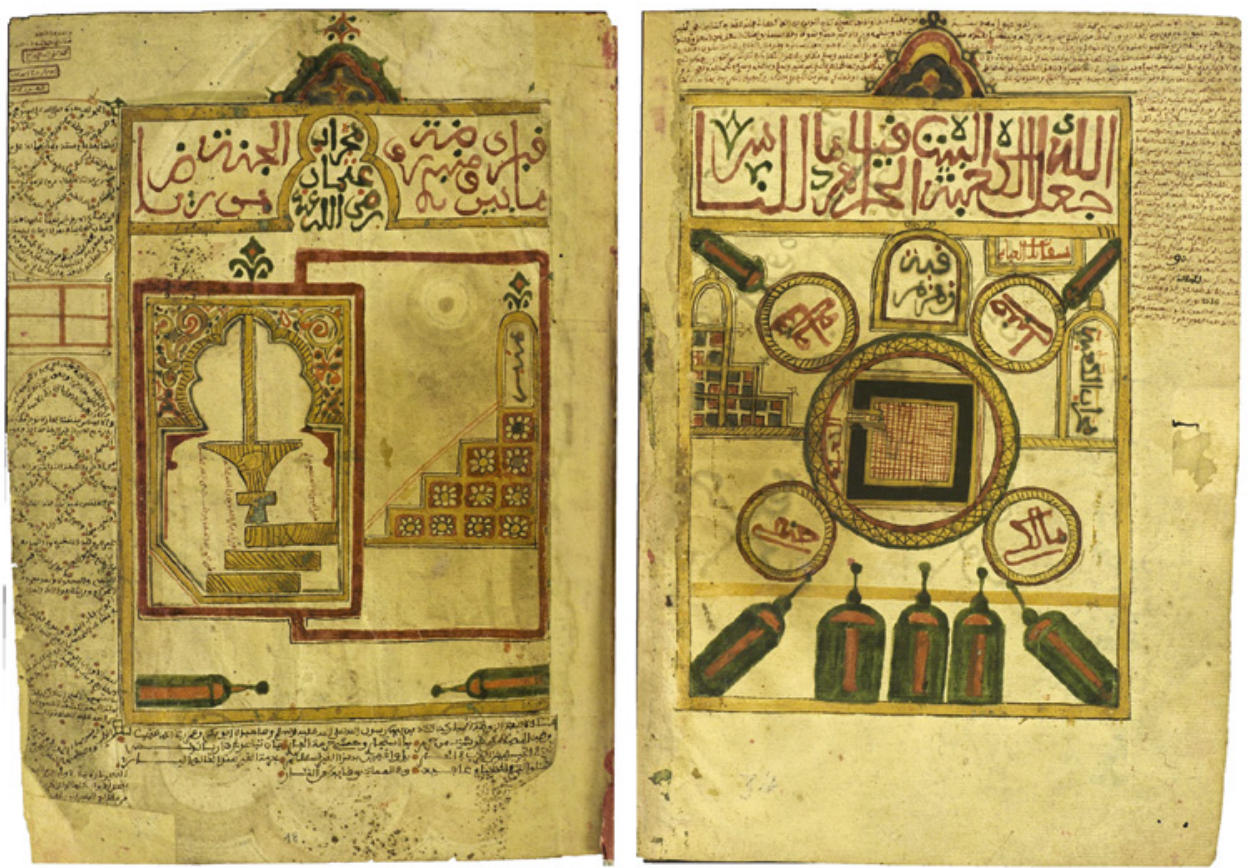

FIGURE 20.24 Representations of the sanctuaries of Mecca and Medina in the Dalāil al-Khayrāt 399K, ff. 17b, 18a, National Library of the Kingdom of Morocco 

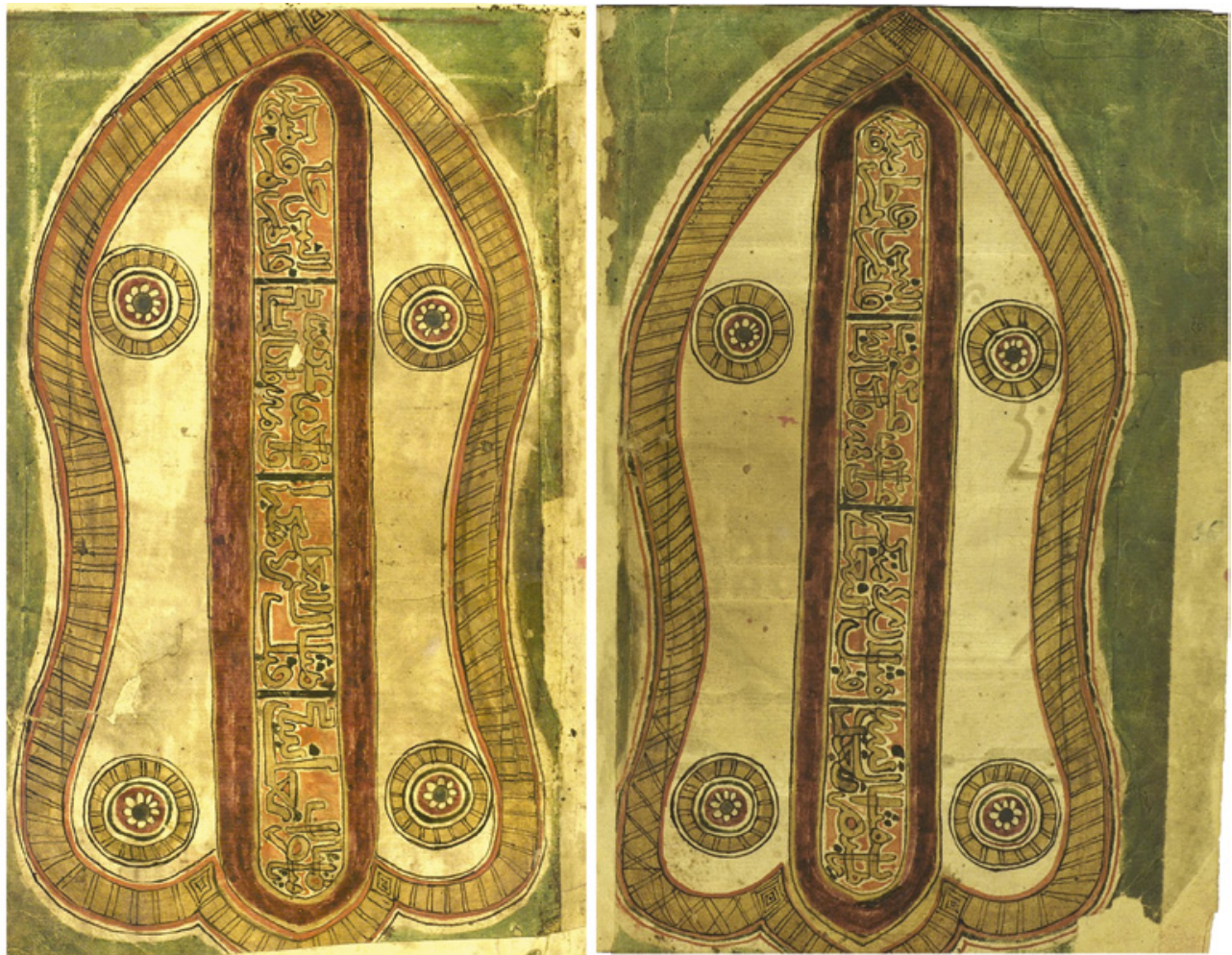

FIGURE 20.25 Representations of the Prophet's sandals (al-na‘l al-nabawī) in the Dalāil al-Khayrāt 399K, ff. 18b-19a, National Library of the Kingdom of Morocco 

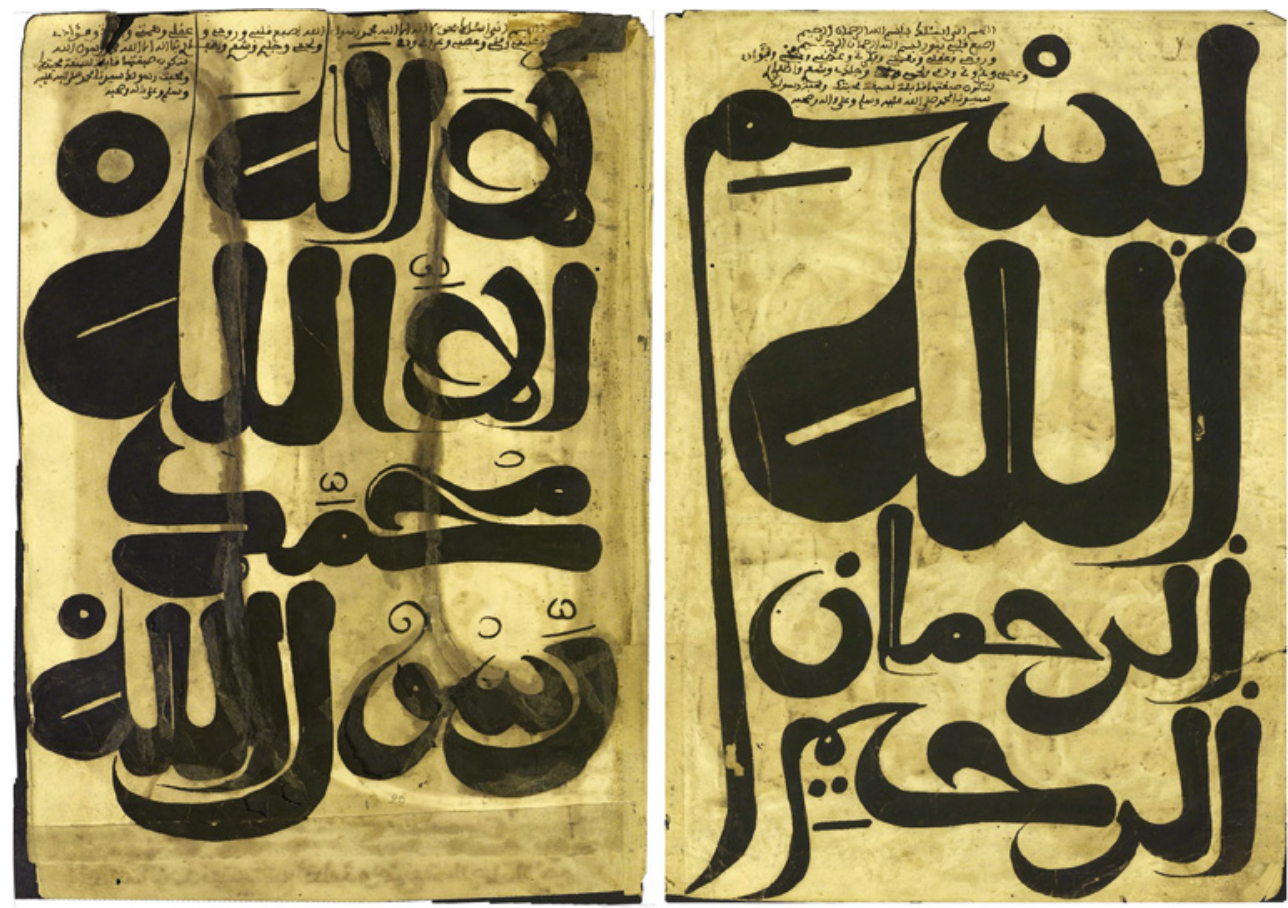

FIGURE 20.26 Monumental writings of the basmala and the profession of faith in the Dalāil al-Khayrāt 399K, f. 19b-20a, National Library of the Kingdom of Morocco 


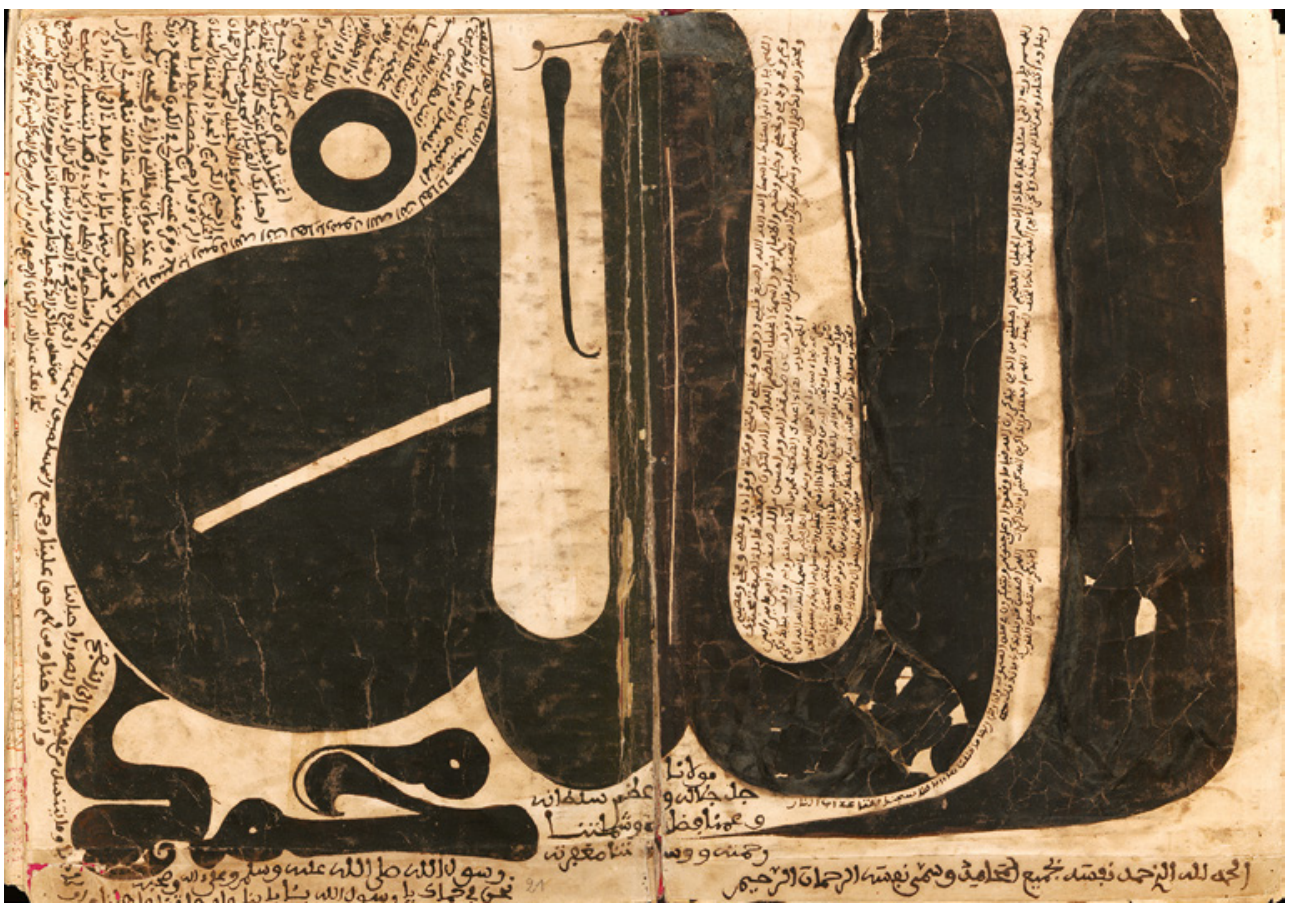

FIGURE 20.27 Monumental inscription of the names of Allāh and the Prophet, Dalāil al-Khayrāt 399K, ff. $20 \mathrm{ob}-21 \mathrm{a}$ 


\section{Bibliography}

\section{Primary Sources}

Jazāirī, 'A. Kitāb al-mawāqif, 3 vols, Damascus, Dār al-yaqaẓa al-'arabiyya, 1966.

Kattānī, M. 'A. Sharh al-shamā'il al-Muhammadiyya li-al-imām al-Tirmidhī (Munyat al-sā'il khulāṣat al-shamā'il), ed. I. Būsbī', Beirut, Dār al-kutub al-ilmiyya, 2016.

Kattānī, M. Munyat al-sāil khulāṣat al-shamā'il, ed. 'A. Khayālī, Casablanca, Markaz al-turāth al-thaqāfī al-maghribī, 2005.

Kattānī, M. b. J. Salwat al-anfās wa muḥādathat al-akyās fi-man uqbira min al-ulamäà wa al-ṣulaḥā’ bi-Fās, A. K. Kattānī, H. b. M.T. Kattānī, M.H. Kattānī (eds.), vol III, Casablanca, Dār al-Thaqāfa, 2004.

Khargūshī, Manāḥil al-shifā’ wa-manāhil al-șafā’ bi-taḥq̄̃ Kitāb Sharaf al-Muștafā, ed.

N. b. H. Ghamrī, Mecca, Dār al-Bashā’ir al-Islāmīya, 2003.

Maqqarī, M. Fatḥ al-Muta'āl fi Madḥ al-Nicāl, ed. A. F. al-Mizyādī, Beirut, 2006

Mizzī, Y. Tuhfat al-aṭrāf bi-márifat al-ațrāf, ed. 'A. Sharaf al-Dīn, Bhiwandi, 1965-1982.

Nabahānī, Y. Afḍal șalāwāt 'alā sayyid al-sādāt, Beirut, n. d.

Nābulusī, 'A. Asrār al-sharīa aw al-fath al-rabbānī wa-l-fayḍ al-raḥmānī, ed. M. 'A. 'Atā, Dār al-kutub al-'ilmīya, Beirut, 1985

Qandūsī, M. Manuscript BNRM 399 K.

Qandūsī, M. Sharāb ahl al-ṣafā fì l-ṣalāt 'alā l-nabīal-muṣtafāe ed. 'A. Hammādī al-Idrīsī, 'Ayn Malīla (Algeria), Dār al-Hudā, 2008.

Qandūsī, M. MS BNRm 1688 D (Taqāyìd mukhtalifa fi ism Allāh al-ą̧zam).

Qandūsī, M. MS BNRM 1699 D.

Qandūsī, M. MS BNRM 2127-2 K.

Qandūsī, M. MS BNRM 2795 D (attributed), ijāza li-al-sulțān al-muqaddas mawlānā Sulaymān fì qirā'at Dalāil al-khayrāt, fol. 361 .

Qandūsī, M. [Ta'sīs I ] = al-Ta'sīs fì al-madākhil 'alā masāwì al-dunyā wa-mahāwì Iblīs, in

S. Layachi ed. Satan Tools Against the Religion of Allah, published on the print-ondemand site lulu.com, 2016.

Qandūsī, M. [Ta'sīs II ] = al-Ta'sìs fìmasāwīal-dunyā wa-mahāwī Iblīs, MN BNRM $2526 \mathrm{~K}$.

Qandūsī, M. MS 162613 [the muṣhaf in 12 volumes], Bibliothèque royale al-Ḥasaniyya de Rabat.

Qushayrī, Lațāîf al-ishārāt, ed. I. Basyūnī, Cairo 1971.

Sharqāwī, M. Dhakhīrat al-muḥtāj fì l-șalāt 'alā șāhịib al-liwā̄'wa-al-tāj:fawātiḥ al-asfār, Rabat, Wizārat al-Awqāf wa-l-Shu'ūn al-Islāmiyya, 2009.

Ṭabarī, M. Jāmi' al-bayān 'an āy al-Qur'ān, ed. M. Shākir, Cairo 1969. 


\section{Secondary Literature}

'Abd al-Razzāq, F. "The Kingdom of the Book: the history of printing as an agency of change in Morocco between 1865 and 1912", PhD diss., University of Boston, 1990.

Abid, H. "Les Dalāill al-Khayrāt d'al-Jazūlī (m. 869/1465): la tradition manuscrite d'un livre de prières soufi au Maghreb du Xe/XVIe au XIII ${ }^{\mathrm{e}} / \mathrm{XIX}^{\mathrm{e}}$ siècles", Doctoral thesis, École Pratique des Hautes Études/PSL, 4 vol. Paris, 2017.

Barbulesco, L. (tr.), Le Paradis des femmes et l'Enfer des chevaux. Relation du Voyage d'Idriss al-'Amraoui, La Tour-d'Aigues, Editions de l'Aube, 1992.

Blair, S. "Pictorial writing", in Islamic Calligraphy, Edinburgh, Edinburgh University Press, 2008, 449-56.

Blair, S. Islamic Calligraphy, Edinburgh University Press, Edinburgh, 2006.

Chih, R. "A New Historiographical Outlook on the Tariqa Muhammadiyya", in J. Malik and S. Zarrabi-Zadeh, eds. Sufism East and West: Mystical Islam and Cross-Cultural Exchange in the Modern World, Boston - Leiden, Brill, 2019, 104-26.

Chodkiewicz, M. (Introduction and translation), Abd el-Kader. Écrits spirituels, Paris, Seuil, 1982.

Cornell, V. Realm of the Saint: Power and Authority in Moroccan Sufism, Austin, University of Texas Press, 1998.

Déroche, F. "Les emplois du Coran, livre manuscrit", in Revue de l'histoire des religions, 218/1 (2001), 43-63.

Déroche, F. "Cercles et entrelacs: format et décor des Corans maghrébins médiévaux", in Comptes rendus de l'Académie des Inscriptions (2001), 593-620.

Déroche, F. "Copier des manuscrits: remarques sur le travail du copiste", Revue des mondes musulmans et de la Méditerranée, 99-100 (November 2002), 133-44.

Déroche, F. "Le Prince et la Nourrice”, Journal of Qur'ānic Studies 19.3 (2017), Edinburgh University Press, $18-33$.

Ernst, W. C. "The Spirit of Islamic Calligraphy: Baba Shah Isfahani's Adab al-mashq", JAOS 112/2 (1992), 279-86.

Gonzalez, V. "Interprétation phénoménologique d'une calligraphie figurative ottomane du musée de Raqqada (Tunisie)", in G. Fløistad, ed. Aesthetics and Philosophy of Art. Contemporary Philosophy: A New Survey, vol 9. Springer, Dordrecht, 2007, $1-21$.

Gruber, Ch. The Praiseworthy One. The Prophet Muhammad in Islamic Texts and Images, Indiana University Press, 2019.

Guesdon, M.-G. and Vernay Nouri, A. L'Art du livre arabe: du manuscrit au livre d'artiste, (exhibition cat., Bibliothèque nationale de France, Site Richelieu, Galerie Mazarine, 9 Octobre 2001-13 Janvier 2002), Paris, Bibliothèque nationale de France, $\mathrm{n}^{\circ} 3$.

Hamès, C. "L'usage talismanique du Coran", in Les usages du Livre saint dans l'islam et le christianisme, Revue de l'histoire des religions, 218/I (2001), 83-95. 
Hamès, C., ed. Coran et talismans. Textes et pratiques magiques en milieu musulman, Paris, Karthala, 2007.

Hamidoune, Mohamed Amine, "La pratique de la "prière sur le prophète" en Islam: Analyse philologique et implications doctrinales", thèse de doctorat sous la direction de Denis Gril, Université Aix-Marseille, 2012.

Ḥammādī al-Idrīsī, 'A. Ḥậ̣̂irat al-qanādisa wa-zāwiyatu-hā al-zìyāniyya al-shādhiliyya bi-hādhihi al-ṣaḥrā' al-jazāirìyya. Tārīkh wa-manāqib, Būsa‘āda, Algeria, 2013.

Ḥammādī al-Idrīsī, 'A. Al-Faỵ̣ al-quddūs fì tarjamat al-'arif bi-llāh sayyidì Muḥammad b. al-Qāsim al-Qandūsī, Dār wāyt Darīm li-l-nashr wa-l-intāj, Algiers, 2018.

Juynboll, G. H. A. Encyclopedia of Canonical Hadīth, Leiden, Brill , 2007.

Khemir, S. "The Art of the Book", in J. Dodds, ed. Al-Andalus: The Art of Islamic Spain, (exhibition cat., The Metropolitan Museum of Art, New York, 1 July-27 September 1992).

Le Baot, M. “Quelques variantes de la 'prière de la Lumière essentielle' du Cheikh Abu-l-Hassan Al-Châdhilî", online, https://leporteurdesavoir.fr/quelques-variantes -de-la-priere-de-la-lumiere-essentielle-du-cheikh-abu-l-hassan-al-chadhili, consulted 30 January 2020.

Maarouf, M. "Saints and Social Justice in Morocco: An Ethnographic Case of the Mythic Court of Sidi Šamharūš", Arabica, 57 (2010), 589-670.

Margoliouth, D. S. "The relics of the Prophet Mohammed", The Muslim World, 27, Hartford (1937), 20-27.

al-Manūnī, M. al-Maṣādir al-'arabiyya li-tārīkh al-Maghrib, Manshūrāt kulliyyat al-ādāb wa-l-‘ulūm al-insāniyya, University of Rabat Muhāmmad v, Rabat, 1990

al-Manūn̄̄, M. Tarīkh al-wirāqa al-maghribiyya: sinā'at al-makhțūtāt al-maghribiyya min al-'așr al-wașịt ilā al-fațra al-mu'āṣira, Rabāt, Manshūrāt Kulliyyat al-ādāb wa-l'ulūm al-insāniyya, 1991.

Meri, J. W. "Relics of Piety and Power in Medieval Islam", Past and Present, $\mathrm{n}^{\circ} 10$, Supplement 10 (2010), Oxford University Press, 106-112.

Rosenthal, F. Ibn Khaldûn, The Muqaddimah: An Introduction to History, Princeton University Press, 1967.

Schick, I. C. "The Content of Form. Islamic Calligraphy between Text and Representation", in B. Bedos-Rezak, J. Hamburger, eds. Sign and Design: script as Image in crosscultural perspective (300-160o CE), Washington, Dumbarton Oaks Research Library and collection, 2016, 173-194.

Schimmel, A. "The primordial dot: Some thoughts about Sufi letter mysticism", JSAI, 9 (1987), 350-356.

Suraqah, A. The Grand Elixir of Invocations. Taken from the book: The Sword of Solicitude for the Seeker of Plenitude (sayf al-inaya li-murid al-Kifaya), published online, Qandusi Publications, 2017, accessible under https://archive.org/details/TheGrand Elixir/mode/2up, last access 24 Feb. 2021. 
Toufiq A. "Introduction", in M. Sharqāwī, Dhakhīrat al-muḥtāj fì al-ṣalāt 'alā șāḥib alliwā’ wa-l-tāj: fawātiḥ al-asfār, Rabat, Wizārat al-Awqāf wa-al-Shu'ūn al-Islāmiyya, 2009.

Vernay-Nouri, A. "Marges, gloses et décor dans une série de manuscrits araboislamiques", Revue des mondes musulmans et de la Méditerranée, 99-100, (2002), $117-31$.

Vimercati Sanseverino, R. Fès et sainteté, de la fondation à l'avènement du Protectorat (808-1912): Hagiographie, tradition spirituelle et héritage prophétique dans la ville de Mawlāy Idrīs. Rabat, Centre Jacques-Berque, 2014. Web: <http://books.openedition .org/cjb/498>.

Vimercati Sanseverino, R. "Penser la voie muhammadienne: Le renouveau soufi à Fès au XIII $/$ XIX e siècle", Studia Islamica 111 (2016), 109-36.

Waley, M. I. "L'ornementation du livre", in F. Déroche ed. Manuel de codicologie des manuscrits en écriture arabe, Bibliothèque nationale de France, 2000, 245-71. 